U. S. DEPARTMENT OF THE INTERIOR

U.S. GEOLOGICAL SURVEY

\title{
The stable isotope geochemistry of jarosite
}

by

Robert O. Rye ${ }^{1}$ and Charles N. Alpers ${ }^{2}$

Open-File Report 97-88

1997

This report is preliminary and has not been reviewed for conformity with U.S. Geological survey editorial standards and stratigraphic nomenclature

${ }^{1}$ U.S. Geological Survey, Box 25046, MS 963, Denver, CO 80225;

${ }^{2}$ U.S. Geological Survey, Placer Hall, 6000 J St., Sacramento, CA 95819-6129 


\section{ABSTRACT}

Jarosite $\left[\mathrm{KFe}_{3}\left(\mathrm{SO}_{4}\right)_{2}(\mathrm{OH})_{6}\right]$ is a common mineral in the weathered portions of many sulfide-bearing mineral deposits and in mine drainages where its formation reflects acidic conditions produced by the oxidation of sulfides (supergene environment). Under special conditions in complicated ground water systems supergene jarosite may be deposited many kilometers from the site of oxidation of sulfides. The mineral also occurs in hot springs and epithermal environments where its formation reflects acidic conditions produced by the oxidation of $\mathrm{H}_{2} \mathrm{~S}$ (steam-heated environment). Like isostructural alunite $\left[\mathrm{KAl}_{3}\left(\mathrm{SO}_{4}\right)_{2}(\mathrm{OH})_{6}\right]$, jarosite contains both sulfate and hydroxyl sites. Jarosite requires considerably higher $\mathrm{Fe}^{3+}$ activity and lower $\mathrm{pH}$ for its formation than alunite (Stoffregen, 1993). Because such extreme conditions probably do not develop in rock-buffered systems, jarosite is not expected to form in the magmatic hydrothermal environment that typically hosts alunite (Rye et al., 1992). Jarosite may form in the magmatic steam environment but no examples have been recognized.

$\delta \mathrm{D}, \delta^{18} \mathrm{O}_{\mathrm{SO}}, \delta^{18} \mathrm{O}_{\mathrm{OH}}$, and $\delta^{34} \mathrm{~S}$ values can be determined for jarosite using modifications of procedures developed for alunite (Wasserman et al., 1992). Experimental fractionation factors (Rye and Stoffregen, 1995) permit interpretation of jarosite isotope data in terms of the history of the parent fluids.

The stable isotope geochemistry of jarosite is similar to that of alunite (Rye et al., 1992) except that $\delta \mathrm{D}$ values for jarosite are usually quite low due to a large ( $-60 \%)$ negative fractionation of hydrogen between jarosite and water. $\delta \mathrm{D}$ and $\delta^{18} \mathrm{O} \mathrm{OH}$ values reflect the isotopic composition of the fluid responsible for jarosite formation; $\delta^{18} \mathrm{O}_{\mathrm{OH}}$ and $\delta^{18} \mathrm{O}_{\mathrm{SO}}$ values can usually be used to distinguish supergene from steam-heated jarosite and $\Delta^{18} \mathrm{OOH}^{-} \mathrm{SO}_{4}$ values can indicate the temperature of formation of steam-heated jarosite; $\delta^{34} \mathrm{~S}$ and $\delta^{18} \mathrm{O}_{\mathrm{SO}_{4}}$ values can also be used to indicate the source(s) of sulfur in the jarosite and the hydro-biogeochemical environment of sulfide oxidation. Jarosite usually forms in the vadose zone and will typically be the youngest mineral in both the supergene and steamheated environments that is datable by $\mathrm{K} / \mathrm{Ar}$ or ${ }^{40} \mathrm{Ar} /{ }^{39} \mathrm{Ar}$ methods. Thus, stable isotope and radiometric age data on jarosite provide information on paleoclimate and tectonic evolution during weathering or hydrothermal episodes. Finally, stable isotope data on jarosite may be useful in understanding processes that produce environmentally damaging acid drainage associated with the weathering and mining of mineral deposits.

Examples and application of the stable isotope geochemistry of jarosite from work with various colleagues are presented from supergene occurrences at Creede, $\mathrm{CO}$; Paradise Peak, NV; Bristol Silver, NV; Apex, UT; Iron Mountain, CA; Rodalquilar, Spain; El Salvador and Chuquicamata, Chile; Golden, NWT Canada; and mid-oceanic ridges as well as from steam-heated occurrences at Marysvale, UT; Sulphur, NV; and Gilbert, NV.

\section{INTRODUCTION}

Jarosite $\left[\mathrm{KFe}_{3}\left(\mathrm{SO}_{4}\right)_{2}(\mathrm{OH})_{6}\right]$, is a common mineral in the weathered portions of many sulfide-bearing mineral deposits (e.g., Blanchard, 1968; Anderson, 1981; Alpers and Brimhall, 1989) and in mine drainages (Nordstrom, 1982; Alpers et al., 1989) where its formation reflects acidic conditions produced by the oxidation of sulfides. Such jarosite occasionally contains a significant resource (e.g., gallium, Bernstein, 1985). The mineral has also been reported in hot springs and shallow epithermal environments where its formation reflects acidic conditions produced by the oxidation of $\mathrm{H}_{2} \mathrm{~S}$ (e.g., Cunningham et al., 1984). Hydrothermal jarosite is locally an important component of alteration that can lead to edifice collapse and landslide hazards on volcanoes such as Mount Rainier, Washington (Zimbelman, 1996) contributing considerable risk to life and property. Sedimentary jarosite has been reported in Australian hypersaline lakes (Alpers, et al., 1992) and in coal environments (Kubisz, 1962); both can be viewed as weathering or sulfide oxidation environments.

Jarosite, like isostructural alunite $\left[\mathrm{KAl}_{3}\left(\mathrm{SO}_{4}\right)_{2}(\mathrm{OH})_{6}\right]$, contains both sulfate and hydroxyl sites; hydrogen, oxygen, and sulfur isotope compositions can now be determined in these sites (Wasserman et al., 1992). Previous stable isotope studies of alunite (Rye et 
al., 1992) demonstrated that comprehensive stable isotope data on sulfur, hydrogen and both oxygen sites provide powerful tools for understanding supergene and shallow epithermal acid-sulfate environments and a potentially useful tool for distinguishing supergene from hydrothermal origins.

The purposes of this presentation are to 1) establish the principles of the stable isotope geochemistry of jarosite, 2) give examples of stable isotope data on jarosite from a number of occurrences, and 3) evaluate the potential application of such data as indicators of environmental and geochemical processes associated with the formation and destruction of mineral deposits. Because jarosite may occur with alunite, comparisons are made between the stable isotope geochemistry of jarosite and that of alunite as previously established by Rye et al. (1992). Background information on the geochemistry of jarosite is followed by presentation of the principles governing the stable isotope systematics of jarosite in the supergene and steam-heated environments. Then, examples of stable isotope data on jarosite from both the supergene and steam-heated environments are presented and evaluated.

\section{Crystal chemistry of jarosite}

\section{BACKGROUND}

Jarosite, like alunite, contains both sulfate and hydroxyl sites (Figure 1). The sulfur and oxygen isotope compositions can be determined on the $\mathrm{SO}_{4}$ site and hydrogen and oxygen isotope compositions can be determined on the $\mathrm{OH}$ site. The techniques used are similar to those developed by Wasserman et al. (1992) for alunite. Both jarosite and alunite can also be dated by radiometric argon techniques including $\mathrm{K} / \mathrm{Ar}$ and ${ }^{40} \mathrm{Ar} /{ }^{39} \mathrm{Ar}$ (e.g., Vasconcelos et al., 1994).

Brophy et al. (1962) observed complete solid solution between jarosite and alunite in their experimental studies. However, extensive solid solution between these minerals in natural samples is uncommon. Also some samples may contain fine-grained mixtures of alunite and jarosite (Alpers et al., 1992). The degree of substitution of Al for Fe in jarosite or the amount of alunite present in a mixed sample must be determined to interpret hydrogen isotope data in terms of fluid compositions because of the large difference between jarosite-water and alunite-water hydrogen isotope fractionations.

Hydronium $\left(\mathrm{H}_{3} \mathrm{O}\right)$ commonly substitutes for $\mathrm{K}$, up to 15 to 25 mole percent in jarosites formed at low temperature (Dutrizac, 1983; Alpers et al., 1989, 1992). For best results, hydronium must be removed by sufficient heating in a vacuum prior to the determination of the hydrogen isotope composition of jarosite (Alpers et al., 1992).

In addition to hydronium, $\mathrm{Na}$ commonly substitutes for $\mathrm{K}$ in jarosite, forming a complete solid solution with natrojarosite. This substitution does not affect jarosite-water isotope fractionations (Rye and Stoffregen, 1995). $\mathrm{NH}_{4}, \mathrm{Ag}, \mathrm{Pb}$, and other elements also substitute for $\mathrm{K}$ in jarosite. The effects of these substitutions on isotope fractionations are unknown, but are probably insignificant at trace levels.

\section{Jarosite chemical stability}

Jarosite precipitates at lower $\mathrm{pH}$ and higher $\mathrm{fO}_{2}$ values than alunite over the entire temperature range of its stability (Figure 2) as shown by Stoffregen (1993). These extreme values limit jarosite formation to the vadose zone above the water table or to environments where fluids with high $\mathrm{fO}_{2}$ values and low $\mathrm{pH}$ values can be obtained, such as shallow silicified rocks with little acid neutralizing capacity.

In magmatic hydrothermal environments alunite precipitates from aqueous sulfate derived from the disproportionation of magmatic $\mathrm{SO}_{2}$ during the condensation of magmatic vapor according to the reaction $4 \mathrm{SO}_{2}+4 \mathrm{H}_{2} \mathrm{O}=3 \mathrm{H}_{2} \mathrm{SO}_{4}+\mathrm{H}_{2} \mathrm{~S}$. In this environment $\mathrm{H}_{2} \mathrm{~S}_{\mathrm{SO}} \mathrm{SO}_{4}$ ratios are buffered by the rocks and typically range from $1: 1$ to $8: 1$ (Rye, 1993). Jarosite is not expected to form in magmatic hydrothermal systems because it is not stable at the buffered $\mathrm{H}_{2} \mathrm{~S} / \mathrm{SO}_{4}$ ratios of fluids in such environments (Stoffregen, 1993).

\section{Stable isotope fractionation factors}

The experimental oxygen isotope fractionations for jarosite and water used to construct 
reference diagrams and to calculate hydrogen and oxygen isotopic compositions of water in fluids in equilibrium with jarosite (Figure 3) are from Rye and Stoffregen (1995). The alunite fractionation factors are from Stoffregen et al. (1994).

The hydrogen isotope fractionations are from experimental and empirical observations as summarized by Rye and Stoffregen (1995). The jarosite fractionations are not known as well as those for alunite. The uncertainty in the hydrogen isotope fractionation for jarositewater at $25^{\circ} \mathrm{C}$ is probably \pm 15 permil.

The oxygen isotope $\mathrm{SO}_{4}$-site water fractionations for jarosite are similar to those for alunite. The oxygen isotope $\mathrm{OH}$-site water fractionations for jarosite are somewhat smaller than those for alunite resulting in a greater sensitivity of jarosite oxygen isotope $\mathrm{SO}_{4}-\mathrm{OH}$ fractionations to temperature. However, the principal difference in the fractionation factors between the two minerals is that jarosite in equilibrium with alunite is depleted in deuterium by about $60 \%$ o (Figure 3 ).

\section{PRINCIPLES OF STABLE ISOTOPE GEOCHEMISTRY AND PREDICTED STABLE ISOTOPE COMPOSITIONS FOR JAROSITE-FORMING ENVIRONMENTS Predicted $\delta D, \delta^{18} O_{S O 4}, \delta^{18} O_{O H}$ and $\delta^{34} S$ systematics of supergene jarosite}

Supergene jarosite is produced from the weathering of sulfide-rich minerals, principally pyrite. It typically occurs in acid rock drainages and in alteration assemblages in the unsaturated zone in topographically controlled zones often underlying or peripheral to zones rich in hematite and goethite such as gossans and leached cappings (Alpers and Brimhall, 1989). The principles of stable isotope geochemistry of supergene jarosite are essentially the same as those for alunite, and isotope data for jarosite can be plotted against the same types of references as shown in Figure 4 (modified from Rye et al., 1992). However, the large difference in $\mathrm{D} / \mathrm{H}$ fractionations and the small difference in $\mathrm{OH}$-site water ${ }^{18} \mathrm{O} / 16 \mathrm{O}$ fractionations between alunite-water and jarosite-water lead to significant differences in $\delta \mathrm{D}$ and $\delta^{18} \mathrm{O} \mathrm{OH}$ values for alunite and jarosite precipitated from water of the same isotopic composition.

The $\delta^{34} \mathrm{~S}$ and $\delta^{18} \mathrm{O}_{\mathrm{SO}} 4$ values of supergene jarosite are kinetically controlled in the same manner as those for alunite (Rye et al., 1992). The $\delta^{34} \mathrm{~S}$ values of supergene jarosite are commonly similar to those for the precursor sulfides (e.g., Field, 1966); variations are possible if aqueous sulfate formed from oxidation of sulfides undergoes bacteriogenic reduction prior to precipitation as jarosite - a process not likely to occur at the low $\mathrm{pH}$ required for jarosite precipitation. However, at such low $\mathrm{pH}$ values oxygen isotope exchange between water and aqueous sulfate is likely to occur if residence times of aqueous sulfate prior to precipitation of jarosite are sufficient (Alpers et al., 1992; 1996).

The $\delta \mathrm{D}$ and $\delta^{18} \mathrm{O}_{\mathrm{OH}}$ values of supergene jarosite (as well as alunite) are controlled by equilibrium exchange and reflect the temperature, $\delta \mathrm{D}_{\mathrm{H} 2 \mathrm{O}}$, and $\delta^{18} \mathrm{O}_{\mathrm{H} 2 \mathrm{O}}$ of the parent fluid. These values for jarosite are expected to plot in a band parallel to the meteoric water line as do $\delta \mathrm{D}$ and $\delta^{18} \mathrm{O} \mathrm{OH}$ values of supergene alunite. Sulfide oxidation reactions are strongly exothermic so supergene alteration may take place over a range of temperatures. An important reference zone for possible $\delta \mathrm{D}-\delta^{18} \mathrm{O}_{\mathrm{OH}}$ values for jarosite in Figure 4 is referred to as the supergene jarosite $\mathrm{OH}$ zone (SJOZ), analogous to the $\mathrm{SAOZ}$ for supergene alunite and defined by the values of jarosite in equilibrium with meteoric water between $20^{\circ}$ and $80^{\circ} \mathrm{C}$.

The $\delta^{18} \mathrm{O}_{\mathrm{SO}} 4$ values of supergene jarosite (as well as alunite) depend on the hydrobiogeochemistry which controls the role of bacteria during sulfide oxidation, and on whether air or water supplies most of the oxygen during sulfide oxidation. An important reference field for possible $\delta \mathrm{D}-\delta^{18} \mathrm{O} \mathrm{SO}_{4}$ values of jarosite in Figure 4 can be defined as the supergene jarosite $\mathrm{SO}_{4}$ field (SJSF) analogous to the SASF for supergene alunite. The large jarosite-water $\mathrm{D} / \mathrm{H}$ fractionation results in an SJSF field smaller than the comparable SASF field in Figure 4. Assumptions for fluid compositions used in the example in Figure 4 are: $\mathrm{T}=20^{\circ}$ to $80^{\circ} \mathrm{C}, \delta \mathrm{D}=-110 \%, \delta^{34} \mathrm{~S}_{\Sigma \mathrm{S}}=0 \%$ o, $\delta^{18} \mathrm{O}_{\mathrm{H} 2 \mathrm{O}}=-15 \%$.

Globally, $\delta \mathrm{D}-\delta^{18} \mathrm{O} \mathrm{SO} 4$ and $\delta \mathrm{D}-\delta^{18} \mathrm{O} \mathrm{OH}$ of most supergene jarosites (as well as alunites) fall within the appropriate reference fields. Exceptions will be expected only 
under special circumstances in standing pools of water where evaporation permits a shift in $\delta \mathrm{D}-\delta^{18} \mathrm{O} \mathrm{OH}$ values or where equilibration of aqueous sulfate with low $\mathrm{pH}$ water permits a shift in $\delta^{18} \mathrm{O}_{\mathrm{SO} 4}$ values such as occurred in the Australian acid playas (Alpers et al., 1992). In the latter case the $\delta \mathrm{D}-\delta^{18} \mathrm{O}_{\mathrm{SO}} 4$ values will plot close to the JAROSITE LINE in Figure 4 as the aqueous sulfate approaches oxygen isotope equilibrium with meteoric water.

\section{Predicted $\delta D, \delta^{18} \mathrm{OSO}_{\mathrm{SO}}, \delta^{18} \mathrm{O}_{\mathrm{OH}}$, and $\delta^{34} \mathrm{~S}$ systematics of steam-heated jarosite}

Steam-heated jarosite forms in the upper portions of hydrothermal systems where sulfuric acid is produced by the oxidation, at and above the water table, of $\mathrm{H}_{2} \mathrm{~S}$ degassed from an underlying hydrothermal system (Rye et al., 1992). Steam-heated jarosite forms in the vadose zone or in shallow localities that have little rock buffering capacity such as highly silicified volcanic rocks.

The principles of stable isotope geochemistry of steam-heated jarosite are the same as those for alunite as described by Rye et al. (1992). Shown in Figure 5 are the predicted compositions of steam-heated jarosite and alunite precipitated from exchanged and unexchanged fluids of assumed isotope compositions. The $\mathrm{OH}$ in jarosite (as in alunite) will precipitate in oxygen and hydrogen isotope equilibrium with parent water. At the low $\mathrm{pH}$ of jarosite stability, precursor aqueous sulfate may be expected to approach oxygen isotope equilibrium with water prior to precipitation of jarosite in steam-heated environments. With internal oxygen isotope equilibrium expected for steam-heated jarosite, $\Delta^{18} \mathrm{O}_{\mathrm{SO}} \mathrm{O}-\mathrm{OH}$ values should vary systematically with temperatures of formation. Sulfur isotope composition of jarosite (as well as of alunite) will be the same as precursor $\mathrm{H}_{2} \mathrm{~S}$ unless exchange occurs between precursor aqueous sulfate and $\mathrm{H}_{2} \mathrm{~S}$ prior to precipitation of jarosite. Assumptions for the example in Figure 5 are: $\mathrm{T}=90$ to $150 \mathrm{C}$; $\delta^{34} \mathrm{~S}=0$ permil; $\delta \mathrm{D}_{\mathrm{H} 2 \mathrm{O}}$ and $\delta^{18} \mathrm{O}_{\mathrm{H} 2 \mathrm{O}}$ of unexchanged meteoric water (fluid-1) $=-80$ and 12 permil, respectively; values for exchanged meteoric water (fluid-2) $=-110$ and -5 permil, respectively.

\section{EXAMPLES OF SUPERGENE JAROSITE}

\section{Creede, Co: The different depositional environments of supergene jarosite and alunite and} the history of paleowater tables

The data shown in Figure 6 are from Rye et al. (1993) who demonstrated how age and isotope data on both supergene alunite and jarosite can be used to date ancient water tables and to reconstruct climate and geomorphic history in the Creede, $\mathrm{CO}$ mining district. Both minerals occur in minor fractures in the upper, oxidized parts of $25 \mathrm{Ma}$ veins mined for $\mathrm{Ag}$ and base metals in the Creede District. Jarosite is also widely distributed as matrix and coatings on clasts in a tongue of the Creede Formation near the vein system in the southern part of the district. Alunite $\mathrm{K} / \mathrm{Ar}$ ages range from 4.8 to $3.1 \mathrm{Ma}$; jarosite ages range from 2.6 to $0.8 \mathrm{Ma}$. Alunite precipitated by reaction of acid sulfate waters with wall rocks or mixing with dilute waters at or below the water table. Jarosite precipitated by evaporation of acid sulfate waters in the vadose zone. The $\delta D$ values of jarosite correlate with age and decrease with elevation to values in equilibrium with present day meteoric water. The large range of $\delta^{34} \mathrm{~S}$ values in jarosite reflects the derivation of sulfate from oxidation of sulfides both in veins $(0 \pm 2 \% 0)$ and in mineralized Creede Formation $(-22$ to $-4 \% o)$. $\delta \mathrm{D}-\delta^{18} \mathrm{O} O \mathrm{OH}$ values of both alunite and jarosite cluster in zones parallel to the meteoric water line as expected for these supergene minerals, indicating deposition over a range of meteoric water isotopic compositions. Calculated $\delta \mathrm{D}_{\mathrm{H} 2 \mathrm{O}}$ values for jarosite fluids show a large range although the values for the youngest jarosite fluids are similar to present day meteoric water in the district. The calculated $\delta \mathrm{D}_{\mathrm{H} 2 \mathrm{O}}$ values of alunite fluids are larger than those of present-day meteoric water. The narrow range for $\delta \mathrm{D}-\delta^{18} \mathrm{O}_{\mathrm{SO} 4}$ values of alunite reflects oxidation of sulfide under wet conditions typical of submerged environments. The greater range in these values for jarosite reflects oxidation of sulfide under more variable and drier conditions typical of the vadose zone. Alunite appears to mark the position of the paleowater table at the end of a period of gentle erosion from 25 to $5 \mathrm{Ma}$ which exposed the tops of the ore bodies in the southern part of the district to oxidation. Jarosite formed in the 
vadose zone during or following canyon cutting related to regional uplift of the southern Rocky Mountains beginning about 2.6 Ma. The study at Creede indicates that stable isotope data and radiometric ages of supergene jarosite along with those of alunite provide a powerful tool for deciphering climate changes and geomorphic that coincide with tectonic events.

\section{Paradise Peak, NV: supergene jarosite and magmatic hydrothermal alunite}

The gold-mercury deposit at Paradise Peak, NV offers the opportunity to compare the stable isotope systematics of supergene jarosite with those of earlier magmatic hydrothermal alunite. We were attracted to a study of the jarosites at Paradise Peak because numerous workers (Thomason, 1987; John et al., 1989; 1991; Rytuba and Heropoulous, 1992) considered the extensive oxidation at the area to be hypogene in origin. Such an interpretation would have important implications for exploration in the district because it would imply the presence of a late hydrothermal system with possible deep extensions. However, recent work by Sillitoe and Lorson (1994), based on data from new open pit exposures and drill holes, strongly indicates that most oxidation occurred during supergene weathering after detachment faulting separated magmatic hydrothermal mineralization from steep feeder faults.

Jarosite occurs in friable powdery ore, as open space fillings in silicified breccias, and semi-massively with hematite in argillized halos to the ore body. D.A. John and E.H. McKee (written commun., 1995) obtained a K-Ar age of $7.8 \pm 0.3 \mathrm{Ma}$ for jarosite from oxidized argillized andesite from above or peripheral to the orebody. Sillitoe and Lorson (1994) obtained a K-Ar age of $10.4 \mathrm{Ma}$ for supergene alunite. John et al. (1991) obtained $\mathrm{K}$-Ar ages of 22 to 18 for hypogene alunites associated with precious-mineral deposition. The 2.6 Ma difference between the supergene alunite and jarosite ages is similar to that observed at Creede, $\mathrm{CO}$ where it was demonstrated that supergene alunite formed at or below the water table whereas supergene jarosite formed in the vadose zone. The difference in age in the minerals probably reflects the progressive lowering of the water table in the area during natural destruction of the mineral deposit by weathering and erosion.

The stable isotope data for alunite and jarosite shown in Figure 7 confirm the interpretation of Sillitoe and Lorson (1994) regarding the magmatic hydrothermal origin of the deposit and the supergene nature of most of the oxidation. The large $\delta^{34} \mathrm{~S}$ values of the alunite require that the sulfur was derived from the disproportionation of magmatically derived $\mathrm{SO}_{2}$. The small $\delta^{34} \mathrm{~S}$ values of the jarosite reflect the values of precursor pyrite in equilibrium with the alunite at the elevated temperatures of deposition. The low $\delta \mathrm{D}$ values of the alunites indicate that most of the magmatic fluids condensed in meteoric water as appears to have been the case in other magmatic hydrothermal deposits of similar age in Nevada (Rye et al., 1992). The range of $\delta \mathrm{D}$ values for jarosite is larger than that for alunite and is consistent with formation of sulfate from the oxidation of sulfides over a range of climatic conditions as proposed by Sillitoe and Lorson (1994). The $\delta^{34} \mathrm{~S}$ values of jarosite are in the range of values for precursor pyrite, and the $\delta \mathrm{D}-\delta^{18} \mathrm{OOH}$ and $\delta \mathrm{D}-\delta^{18} \mathrm{O} S \mathrm{SO}$ values are in the fields predicted for supergene jarosite.

One of the observations cited by John et al. $(1989 ; 1991)$ and Rytuba and Heropoulous (1992) supporting a hypogene origin for jarosite at Paradise Peak was the occurrence of cinnabar and native sulfur intergrown with clear crystals of jarosite at some localities. This mineral assemblage requires that $\mathrm{H}_{2} \mathrm{~S}$ was present in the fluids at the site of the jarosite deposition. This $\mathrm{H}_{2} \mathrm{~S}$ may have derived from deep hydrothermal fluids or perhaps from organic matter in the sedimentary section of the nearby basin. It may also have derived from the bacteriogenic reduction of aqueous sulfate formed during weathering of the deposit. In support of the latter possibility, Hamlin and Alpers (1996) present evidence that $\mathrm{H}_{2} \mathrm{~S}$ can be derived from the bacteriogenic reduction of sulfate in low $\mathrm{pH}$ solutions in mine drainages. Detailed sulfur isotope data on the cinnabar are needed to resolve the origin of the $\mathrm{H}_{2} \mathrm{~S}$ that led to cinnabar deposition. Cinnabar and jarosite could not have precipitated in chemical equilibrium from the same fluid because jarosite requires a much 
lower $\mathrm{pH}$ and higher $\mathrm{fO}_{2}$ for precipitation. The jarosite could be either steam-heated or supergene depending on whether the aqueous sulfate was derived from the oxidation of $\mathrm{H}_{2} \mathrm{~S}$ or of sulfides. In either case the fact that jarosite and cinnabar are intergrown requires a fluctuation in the level of the water table that would permit alternating cinnabar and jarosite deposition. Unfortunately we do not have radiometric ages on the jarosite crystals. Such ages are important for exploration in the district because the $\mathrm{H}_{2} \mathrm{~S}$ could be related to an underlying and unrecognized hydrothermal system.

\section{Apex, UT and Bristol Silver, NV: supergene jarosite}

Gallium-bearing jarosite-family minerals occur in the extensive oxidized zone of the Apex mine in southwestern Utah. Geology and mineralogy were described by Bernstein (1985) and by Dutrizac et al. (1986). The primary copper and lead ores in breccia pipes that developed in the Pennsylvanian Callville Limestone are oxidized to at least $425 \mathrm{~m}$ below the present surface. Most of the primary copper-rich ore was removed during previous mining operations leaving behind iron-rich minerals that have been mined for germanium and gallium. Gallium occurs chiefly in plumbian jarosite. Geochemcial characteristics of the primary ores were studied by Petersen and Mahin (1988) and Mahin (1990). K-Ar dating of hydrothermal muscovite indicates an age of $200 \mathrm{Ma}$ for primary mineralization whereas $\mathrm{K}-\mathrm{Ar}$ ages on jarosites give mid- to Late-Miocene dates for the supergene alteration corresponding to the timing of the Basin and Range extension in southwestern Utah (Petersen and Mahin, 1988). Textural and geochemical observations by Mahin (1990) indicate that most of the jarosite is likely supergene but that some could be hypogene. However, as previously noted in the discussion of Paradise Peak, hypogene and supergene fluids can mix in the shallow environment of jarosite deposition. Furthermore supergene fluids could be recharged into the hydrothermal system leading to the deposition of jarosite with the appearance of hypogene mineralization, but with a partially supergene stable isotope signature

Jarosite from the Pioche district, Nevada, has been used for some of the definitive $x$ ray diffraction work on this mineral (Hendricks, 1937; Kato and Miura, 1977). The deeply oxidized ores of the Bristol Silver mines, located about $24 \mathrm{~km}$ northeast of Pioche, are known to contain abundant jarosite, thought to be of supergene origin (Westgate and Knopf, 1932). Primary ore deposits of the district are irregular, vein-like or pipelike leadsilver replacement bodies that generally occur along fissure-localized breccias in the limestone member of the Highland Peak Formation.

The stable isotope systematics of the jarosites analyzed from both Apex and Bristol Silver (Figure 8) are characteristic for supergene jarosite in that $\delta \mathrm{D}-\delta^{18} \mathrm{OSO}_{\mathrm{S}}$ and $\delta \mathrm{D}$ $\delta^{18} \mathrm{O}_{\mathrm{H} 2 \mathrm{O}}$ values plot in the appropriate reference fields. The age of jarosite from the Bristol Silver mines is not known but the $\delta \mathrm{D}-\delta^{18} \mathrm{O}_{\mathrm{SO}} 4$ values of are jarosite quite different than those at Apex suggesting that the deposits were oxidized at different times under different climatic and hydrogeological conditions.

\section{Summary of supergene jarosite stable isotope systematics}

The stable isotope compositions of supergene jarosites from various oxidized sulfide occurrences over a range of latitudes are shown in Figure 9. These data are compared with those for supergene alunite over a range of latitudes from Rye et al. (1992). These jarosite samples are from the oxidized zones of porphyry copper deposits at El Salvador and Chuquicamata, Chile, the acid mine waters from the volcanogenic massive sulfide deposit at Iron Mountain, California (Alpers et al., 1989), the pyrite-rich shale at Golden, NWT (Michel and Van Everdingen, 1987), the magmatic-hydrothermal gold-alunite deposit at Rodalquilar, in southern Spain (Arribas, 1992 and Arribas et al., 1995), oceanic ridge massive sulfides (Alt et al., 1987) and near-surface playa sediments at Lake Tyrrell, an acid saline lake in southern Australia (Alpers et al., 1992) as well as the deposits already discussed. Where information is available, the $\delta^{34} S$ values of the supergene jarosite are within the range observed for their respective precursor sulfides. The $\delta \mathrm{D}-\delta^{18} \mathrm{O}_{\mathrm{OH}}$ values for almost all supergene jarosites lie within or near the supergene jarosite $\mathrm{OH}$ zone (SJOZ) 
and the $\delta \mathrm{D}-\delta^{18} \mathrm{O}_{\mathrm{SO} 4}$ values for all supergene jarosite except those from Lake Tyrrell lie within the supergene jarosite $\mathrm{SO}_{4}$ field (SJSF). The aqueous sulfate at Lake Tyrrell has undergone extensive ${ }^{8} \mathrm{O} /{ }^{\circ} \mathrm{O}$ exchange with acidic water in the aquifer feeding the lake over hundreds of years prior to precipitation as jarosite causing an increase in $\delta^{18} \mathrm{OSO}_{\mathrm{SO}}$ values (Alpers et al., 1992). The data for supergene jarosite show the same latitudedependent $\delta \mathrm{D}-\delta^{18} \mathrm{O}_{\mathrm{SO} 4}$ and $\delta \mathrm{D}-\delta^{18} \mathrm{O}_{\mathrm{OH}}$ as alunite (Rye et al., 1992) but with about 60 permil lower $\delta \mathrm{D}$ values. Another difference in stable isotope systematics is that supergene alunites will locally have enriched $\delta^{18} \mathrm{O}_{\mathrm{SO} 4}$ and $\delta^{34} \mathrm{~S}$ values as a result of residual enrichments caused by preferential reduction of $16 \mathrm{O}$ and ${ }^{32} \mathrm{~S}$ relative to ${ }^{18} \mathrm{O}$ and ${ }^{34} \mathrm{~S}$ during bacteriogenic sulfate reduction. This is not as likely to happen for jarosite because the low $\mathrm{pH}$ required for jarosite formation probably restricts the activity of sulfate reducing bacteria.

Supergene systems involving jarosite deposition can be diverse. Most supergene jarosite is probably precipitated very near the site of sulfide oxidation. However, at Lake Tyrrell, southeastern Australia, the site of jarosite deposition is kilometers removed from that of sulfide oxidation (Macumber, 1992). In some cases such as at Paradise Peak, NV supergene fluids that precipitate jarosite may mix with hypogene fluids that precipitate more reduced minerals. Fluctuations in the position of the interface between these fluids may result in intergrown jarosite and cinnabar deposition. Detailed stable isotope studies coupled with detailed petrographic or time-space studies can be used to trace the fluid history of individual jarosite occurrences.

\section{EXAMPLES OF STEAM-HEATED JAROSITE Marysvale, UT: Steam-heated jarosite and alunite}

The replacement alunite and jarosite deposits at Marysvale, Utah, have been described most recently by Cunningham et al. (1984). The alunite and jarosite replace intermediate composition volcanic rocks in several hydrothermally altered areas, roughly circular in plan and up to $3 \mathrm{~km}$ in diameter clustered around the $23 \mathrm{Ma}$ Central Intrusive. K/Ar ages of alunite are coincident with that of the Central Intrusive which hosts the uranium deposits of the Central mining area (Steven et al., 1979). The jarosite has not been dated. In each area, the alteration is zoned vertically from a silica cap down through a hematite zone, then a jarosite zone, into an alunite zone, and finally into a propylitic zone. Alunite is much more abundant than jarosite and is ringed laterally by a kaolinite zone (Cunningham et al., 1984). Both alunite and jarosite clearly formed in the steam-heated environment of a geothermal system. The stable isotope data on jarosite from one of the replacement deposits are compared with the data (Rye et al., 1992) on alunite from eight different replacement deposits in Figure 10. The $\delta^{34} \mathrm{~S}$ values for alunites and jarosite are both much larger than those of the pyrites in the underlying propylitic zone suggesting exchange of the aqueous sulfate with the $\mathrm{H}_{2} \mathrm{~S}$ in the system. The $\Delta^{18} \mathrm{O}_{\mathrm{SO} 4-\mathrm{OH}}$ value for jarosite gives an apparent temperature of $370^{\circ} \mathrm{C}$ compared with $90^{\circ}$ to $160^{\circ} \mathrm{C}$ for alunites (Rye et al., 1992). The unrealistically high temperature for jarosite probably reflects lack of complete oxygen isotope equilibrium between aqueous sulfate and water in the hydrothermal fluid. Jarosite occurs higher in the system than alunite and the residence time of aqueous sulfate prior to jarosite precipitation was probably not sufficient for oxygen isotope equilibration with meteoric water. Consistent with this interpretation the $\delta^{34} \mathrm{~S}$ value of jarosite does not reflect as much exchange between aqueous sulfate and $\mathrm{H}_{2} \mathrm{~S}$ as do the values for alunite. The $\delta \mathrm{D}$ values of jarosite are about 60 permil lower than those of alunite consistent with precipitation of both minerals from the same fluid. Consistent with a steam-heated origin, the $\delta^{18} \mathrm{O}_{\mathrm{SO}}-\delta \mathrm{D}$ and $\delta^{18} \mathrm{O}_{\mathrm{OH}^{-}} \delta \mathrm{D}$ values of jarosite fall outside the SJSF and SJOZ, respectively.

Crofoot/Lewis deposit, Sulphur district, NV: Steam-heated jarosite and alunite, and supergene jarosite

The information presented here on the Crofoot/Lewis deposit in the Sulphur district, NV is from Ebert (1996) and Ebert and Rye (in press). It is an adularia-sericite type (low- 
sulfidation) Au-Ag deposit, with a well preserved paleosurface containing abundant opaline sinters, widespread silicification, bedded hydrothermal eruption breccias, and a large zone of acid-sulfate alteration. Radiogenic isotope dates indicate that the system was relatively long lived, with hydrothermal activity starting around $4 \mathrm{Ma}$ and extending, at least intermittently, for at least the next $3 \mathrm{Ma}$. Field evidence shows that the near-surface zone of acid-sulfate alteration formed in a steam-heated environment within an active geothermal system. Acid-sulfate alteration overprinted low-grade disseminated adularia-sericite type mineralization, resulting in the leaching of low-grade Au and Ag and redistribution into ore grade concentrations in open space fractures at the top of the water-saturated zone and within a few tens of meters of the paleo water-table. Supergene jarosite can also be recognized

The stable isotope systematics of steam-heated and supergene jarosite from the Sulphur district can be compared with each other and the systematics of both can be compared with those of steam-heated alunite in Figure 11. Dark brown jarosite crystals up to $4 \mathrm{~mm}$ form narrow veinlets that cut the acid-leach zone. As there is native sulfur locally and no evidence of weathered sulfides above, lateral to or immediately below the sample, a supergene origin is unlikely. This jarosite has an elevated (exchanged) value of $\delta^{34} \mathrm{~S}$ (as do most alunites) and a $\Delta^{18} \mathrm{O}_{\mathrm{SO}} 4-\mathrm{OH}$ value which gives a temperature of $70^{\circ} \mathrm{C}$ consistent with a fluid inclusion filling temperature of $87^{\circ} \mathrm{C}$. With a $\mathrm{K}-\mathrm{Ar}$ age of $0.7 \pm 0.2 \mathrm{Ma}$ the jarosite is the youngest hydrothermal mineral in the deposit. In contrast two samples of cryptocrystalline, presumed supergene jarosite overlying unoxidized opal-K-feldspar alteration which has not been acid leached have lower (unexchanged) $\delta^{34} S$ values and give unreasonable $\Delta^{18} \mathrm{O}_{\mathrm{SO}} 4-\mathrm{OH}$ temperatures. These samples, which have not been dated, have less negative $\delta \mathrm{D}$ values than the steam-heated jarosite, probably reflecting drier climate. The large range of $\delta \mathrm{D}$ values of both alunite and jarosite translate into almost a 60 permil range in the $\delta \mathrm{D}$ of meteoric water in the hydrothermal fluids suggesting significant climate changes during the long life of the system. The study shows the potential of combined age and isotope data on alunite and jarosite to relate ore deposition to climate changes in the great basin.

\section{Gilbert NV: Steam-heated (?) jarosite and alunite}

Jarosite from the Gilbert district is spectacularly coarse-grained. It is exceptionally clear and well banded with brown crystals up to $1 \mathrm{~cm}$ thick and with thin interbands of fine-grained yellow jarosite which appears to grow preferentially on certain crystal faces. The banded jarosite is analogous in appearance to magmatic steam alunite at Alunite Ridge, Utah. The jarosite however, does not have saw-tooth $\mathrm{P}_{2} \mathrm{O}_{5}$ concentrations that coincide with the banding (P. Vasconcelos, written commun., 1994) as observed in the Alunite Ridge alunites (Cunningham et al., 1996) and which would be suggestive of a magmatic steam origin as discussed in the next section. The Gilbert district was first described by Ferguson (1928). The geochemistry of ores and altered rocks in the Gilbert district was reported by Nash et al. (1985). Most of the properties in the district are gold prospects in locally silicified and brecciated Tertiary volcanic rocks near masses of intrusive rhyolite. The jarosite was collected from an isolated knob about $10 \mathrm{~m}$ in diameter near an area that has extensive replacement alunite. From these combined observations we interpret that the jarosite and alunite are both steam-heated.

The stable isotope systematics of jarosite and alunite in Figure 12 also suggest that they are both steam-heated in origin. Alunite has $\delta^{18} \mathrm{O}_{\mathrm{SO}}-\delta \mathrm{D}$ and $\delta^{18} \mathrm{O}_{\mathrm{OH}}-\delta \mathrm{D}$ values and jarosite has $\delta^{18} \mathrm{OSO}_{\mathrm{SO}}-\delta \mathrm{D}$ values outside of the supergene reference fields which implies a steam-heated origin for both minerals. The temperatures calculated from the $\Delta^{18} \mathrm{O}_{\mathrm{SO}} 4-\mathrm{OH}$ values range from $60^{\circ}$ to $170^{\circ} \mathrm{C}$ for jarosite compared to an unrealistic temperature of $10^{\circ} \mathrm{C}$ for alunite. However, temperatures calculated from $\Delta^{18} \mathrm{O}_{\mathrm{SO}} 4-\mathrm{OH}$ values for steam-heated alunites are not always realistic because aqueous sulfate does not always reach equilibrium with the water in the hydrothermal fluids prior to alunite deposition (Rye et al., 1992; Ebert and Rye, in press). The average difference of $\delta \mathrm{D}$ values between alunite and jarosites is about 60 permil which suggests that both minerals precipitated from fluids of similar 
isotopic composition.

\section{Summary of steam-heated jarosite stable isotope systematics}

The stable isotope data of steam-heated jarosite occurrence shown in the examples are summarized in Figure 13. These systematics can be contrasted with those of supergene jarosite shown previously (Figs. 6-9). The Marysvale and Crofoot/Lewis jarosites can be shown on geologic grounds to be steam-heated in origin. We also infer a steam-heated origin for these jarosites from the isotope data alone. This is because such jarosites typically form from isotopically exchanged water resulting in jarosites with $\delta \mathrm{D}-\delta^{18} \mathrm{O}_{\mathrm{SO}}$ and $\delta \mathrm{D}-\delta^{18} \mathrm{O} \mathrm{OH}$ values outside of the supergene reference fields. The Gilbert jarosite appears to have formed in a steam-heated environment on geologic grounds; a steam-heated origin is consistent with, but not proven by, the stable isotope data. The Crofoot/Lewis jarosite has been dated by radiogenic techniques and its age is younger than associated steam-heated alunite but consistent with its formation from the same hydrothermal system that created the ore deposit. It is important that steam-heated jarosites be dated because they will typically be the youngest datable hydrothermal mineral and their ages provide an excellent opportunity to determine the duration of the hydrothermal system. Jarosites with ages significantly younger than the main system could indicate the presence of a younger unrecognized system that should be evaluated for its ore potential. As shown by the tie lines in Figure 13 apparent temperatures computed from $\Delta^{18} \mathrm{O}_{\mathrm{SO}}{ }^{-} \mathrm{OH}$ values of steam heated jarosite range $60^{\circ}$ to $370^{\circ} \mathrm{C}$.

\section{THE POSSIBILITY OF MAGMATIC STEAM JAROSITES}

It was pointed out earlier that magmatic hydrothermal jarosites are not expected to form because the necessary $\mathrm{pH}$ and $\mathrm{fO}_{2}$ conditions for jarosite stability probably do not occur in deep rock-dominated hydrothermal environments such as they do for alunite. Alunite also precipitates from $\mathrm{SO}_{2}$-rich fluids in a magmatic steam environment distinct from the steamheated environment described previously (Rye et al., 1992). Theoretically jarosite could also form in this environment, although we have not identified any unequivocal examples. The classical occurrence for magmatic steam alunite is at Alunite Ridge near Marysvale, Utah. There, the world's largest, purest, coarse-grained vein alunite deposits fill near vertical fissures, up to $20 \mathrm{~m}$ wide. The alunite is present mostly as $1-3 \mathrm{~cm}$ multiple layers of plumose crystals that have filled fissures from the walls-inward. These alunites have only been observed in tensional environments that allow for rapid degassing of magmatic vapor. The $\mathrm{SO}_{2}$-rich fluids result from shifts in gas equilibria during high-temperature low-pressure degassing of magmatic vapor. In contrast to the magmatic hydrothermal environment which results from the condensation of magmatic vapor, alunite forms in the magmatic steam environment during the expansion of magmatic vapor in open fractures. The necessary low $\mathrm{pH}$ for alunite formation results from the magmatic components in the vapor fluid and the high $\mathrm{fO}_{2}$ results either from the entrainment of atmospheric oxygen or from auto-oxidation involving the loss of $\mathrm{H}_{2}$ from the vapor fluid. The coarsely banded alunite from Alunite Ridge, Marysvale, UT show saw-tooth $\mathrm{P}_{2} \mathrm{O}_{5}$ concentration variations in the individual bands (Cunningham et al., 1996) which are interpreted to be related to the degassing of magma. Thus, each band represents a burst of magmatic steam (Rye et al., 1992). Such magmatic steam alunites are characterized by magmatic signature $\delta D$ values, disequilibrium $\Delta^{18} \mathrm{O}_{\mathrm{SO}} 4-\mathrm{OH}$ values and complete sulfur isotope disequilibrium in which $\delta^{34} \mathrm{~S}$ values reflect that of total sulfur in the system. The lack of sulfur isotope equilibrium results from the very rapid ascent of the vapor fluids (Rye, 1993) such that disproportionation of $\mathrm{SO}_{2}$ does not occur.

The predicted isotopic compositions of magmatic steam jarosite at $200^{\circ} \mathrm{C}$ in equilibrium with magmatic fluids the same composition as those at Alunite Ridge along with the isotope compositions of the Alunite Ridge alunites are shown in Figure 14. The banded samples from Gilbert, NV are the only jarosites that we have analyzed with textures consistent with such an origin, but the individual bands of these samples do not show the saw tooth $\mathrm{P}_{2} \mathrm{O}_{5}$ concentrations (P. Vasconcelos, written commun., 1994), nor are the $\delta D$ signatures typical 
of a magmatic hydrothermal origin.

\section{CONCLUSIONS}

Stable isotope systematics can be used to (1) distinguish supergene from steam-heated jarosite, (2) to estimate the temperature of formation of steam-heated jarosite and (3) to trace the hydrogeochemical/biogeochemical history of parent fluids in jarosite deposition. Perhaps most significantly $\delta \mathrm{D}$ values of jarosite of both steam-heated and supergene jarosite can be combined with radiogenic age data to trace climatic changes in response to tectonic evolution.

Steam-heated jarosite in which the aqueous sulfate was derived from the shallow oxidation of $\mathrm{H}_{2} \mathrm{~S}$ has been recognized in the replacement alunite deposits at Marysvale, UT, in the Crofoot/Lewis acid-sulfate gold deposit at the Sulphur district, NV, and also probably in the Gilbert district, NV. The recognition of steam-heated jarosite with appropriate radiometric ages could have important exploration implications in some areas. Such jarosite will typically be the youngest datable hypogene mineral. Radiometric age and stable isotope data can be combined to date the duration of hydrothermal activity as well as to trace the climate and hydrogeology during its waning stages. Very young ages and anomalous $\delta \mathrm{D}$ values could indicate renewed hydrothermal activity under different climate and tectonic regimes. Steam-heated jarosite has distinct stable isotope systematics characterized by meteoric-water $\delta \mathrm{D}$ values, large $\delta^{18} \mathrm{O}_{\mathrm{SO}} 4$ values that reflect equilibration with water in the parent fluid, $\Delta^{18} \mathrm{O}_{\mathrm{SO}} \mathrm{O}-\mathrm{OH}$ values that may give temperatures of deposition and $\delta^{34} \mathrm{~S}$ values that reflect exchange of aqueous sulfate with $\mathrm{H}_{2} \mathrm{~S}$ prior to precipitation. As Stoffregen (1993) pointed out, the occurrence of hydrothermal jarosite is limited by the extreme $\mathrm{pH}$ and $\mathrm{fO}_{2}$ conditions required for formation. Limited amounts of steam-heated jarosite can form in the vadose zone and in rocks (such as highly silicified volcanics) that have very little acid-neutralizing capacity.

Supergene jarosites in which the aqueous sulfate was derived from the oxidation of sulfides also have distinct stable isotope systematics characterized by both $\delta^{18} \mathrm{O}_{\mathrm{SO}}-\delta \mathrm{D}$ and $\delta^{18} \mathrm{O}_{\mathrm{OH}^{-}} \delta \mathrm{D}$ values that fall in the appropriate reference fields. Unlike supergene alunite, $\Delta^{18} \mathrm{O}_{\mathrm{SO}} \mathrm{-OH}$ values for supergene jarosite will often be positive, a fact that reflects the relatively rapid oxygen isotope exchange rate between precursor aqueous sulfate and water at the low $\mathrm{pH}$ of jarosite formation. This low $\mathrm{pH}$ will also greatly restrict bacteriogenic reduction of sulfate resulting in $\delta^{34} S$ values for jarosite that will normally not be shifted from those of precursor sulfides. Finally, because the reactions involved in the oxidation of sulfides are strongly exothermic, some supergene jarosites could have formed at high enough temperatures to have isotopic and chemical characteristics similar to those formed in the steam-heated environment. Supergene ground water systems can be quite complicated with the site(s) of sulfide oxidation removed by several kilometers from the site of jarosite deposition, such as at Lake Tyrrell, southeastern Australia. Supergene fluids can also be recharged into shallow hydrothermal systems or may interface with hypogene fluids such as is inferred to have occurred at Paradise Peak, NV.

Finally, coarse banded jarosite may also form in the magmatic steam environment but no examples have been recognized.

\section{ACKNOWLEDGMENTS}

This study has been conducted in cooperation with a number of colleagues engaged in more comprehensive studies of several of the examples chosen for investigation. Shane Ebert conducted the study of the Crofoot/Lewis deposit as part of his recently completed Ph.D. thesis at the University of Western Australia. Skip Cunningham has long been the source of samples and geologic and mineralogic information on the Marysvale district. Studies of supergene jarosite in the Creede district and discussions with Phil Bethke, Tom Steven, and Marv Lanphere greatly expanded our horizons about the potential of the stable isotope geochemistry of jarosite as an indicator of climate and tectonic evolution. David John introduced us to the Paradise Peak, NV deposit and supplied most of the samples from the deposit as well as a sample of supergene jarosite from the Sulphur district, NV. 
Ted McKee determined the age of the jarosite from the area. Roger Stoffregen who pioneered modern geochemical studies of jarosite also supplied samples of jarosite crystals from Paradise Peak. Ted Theodore first brought the Gilbert District jarosite to our attention. Jeff Alt supplied the sample from the mid-oceanic ridge; Fred Zeiner supplied the sample from Chuquicamata; Cy Field supplied the samples from El Salvador. A large number of the stable isotope measurements were made by Carol Gent throughout the course of this study.

\section{REFERENCES}

Alpers, C.N., and Brimhall, G.H., 1989, Paleohydrologic evolution and geochemical dynamics of cumulative supergene metal enrichment at La Escondida, Atacama Desert, northern Chile: Econ. Geol., v., 84, p. 229-255.

Alpers, C.N., Nordstrom, D.K., and Ball, J.W., 1989, Solubility of jarosite solid solutions precipitated from acid mine waters, Iron Mountain, California, USA.: Sciences Geologiques Bulletin, v. 42, p. 281-298.

Alpers, C.N., Rye, R.O., Nordstrom, D.K., White, D.L., and King, B.S., 1992, Chemical crystallographic and isotopic properties of alunite and jarosite from acidhypersaline Australian lakes: Chem. Geol., v. 96, p. 203-226.

Alpers, C.N., Rye, R.O., and Nordstrom, D.K., 1996, Stable isotope systematics of S and $\mathrm{O}$ in aqueous and mineral sulfates from hyper-acid environments (abs.): Chapman Conference on Crater Lakes, Terrestrial Degassing and Hyper-Acid Fluids in the Environment, Sept., 4-9, 1996, Crater Lake, OR, American Geophys. Union, Washington, DC., p. 27.

Alt, J.C., Lonsdale, P., Haymon, R., and Muehlenbachs, K., 1987, Hydrothermal sulfide and oxide deposits on seamounts near $21^{\circ}$ north, East Pacific Rise: Geol. Soc. Amer. Bulletin, v. 98, 157-168.

Anderson, J.A., 1981, Characteristics of leached capping and techniques of appraisal: in Advances in Geology of the Porphyry Copper Deposits, Southwestern North America (ed. S.R. Titley), University Arizona Press: Tucson Arizona, p. 245-287.

Arribas, A., Jr., 1992, Geology and geochemistry of the Rodalquilar gold alunite deposit; relationship to other hydrothermal ore deposits in south-eastern Spain: Unpublished Ph.D. thesis, Ann Arbor, Michigan, University of Michigan, 320p.

Arribas, A., Jr., Cunningham, G.G., Rytuba, J.J., · Rye, R.O., Kelly, W.C., Podwysocki, M.H., McKee, E.H., and Tosdal, R.M., 1995, Geology, geochronology, fluid inclusions, and isotope geochemistry of the Rodalquilar gold alunite deposit, Spain: Econ. Geol., v. 90, p. 795-822.

Bernstein, L.R., 1985, Geology and mineralogy of the Apex mine, Washington County, Utah: U.S. Geological Survey Open File Report 85-511, 21 p.

Blanchard, R., 1968, Interpretation of leached outcrops. Nevada Bureau Mines Bulletin, 66, p.

Brophy, G.P., Scott, E.S., and Snellgrove, R.A., 1962, Sulfate studies II. Solid solution between alunite and jarosite: Am. Mineralogist, v. 78, p. 73-90.

Cunningham, C.G., Rye, R.O., Steven, T.A., and Mehnert, H.H., 1984, Origins and exploration significance of replacement and vein-type alunite deposits in the Marysvale volcanic field, west central Utah: Econ. Geol., v. 79, p. 50-71.

Cunningham, C.G., Rye, R.O., Bethke, P.M., Logan, M.A.V., 1996, Formation of coarse-grained vein alunite by degassing of an epizonal stock: .): Chapman Conference on Crater Lakes, Terrestrial Degassing and Hyper-Acid Fluids in the Environment, Sept., 4-9, 1996, Crater Lake, OR, American Geophys. Union, Washington, DC., p. 27.

Dutrizac, J.E., 1983, Factors affecting alkali jarosite precipitation : Metall. Trans., B., v. 14B, p. 531-539.

Dutrizac, J.E., Jambor, J.L., and Chen, T.T., 1986, Host minerals for the galliumgermanium ores of the Apex mine, Utah: Econ. Geol. v. 81, p. 946-950.

Ebert, S.W., 1996, The anatomy and origin of the Crofoot/Lewis mine, a low-sulfidation 
hot-spring type gold-silver deposit located in northwest Nevada: unpub. Ph.D thesis, University of Western Australia, p. 228.

Ebert, S.W., and Rye, R.O., Origin of the Crofoot/Lewis hot-spring gold-silver deposit, Sulphur, Nevada and significance of paleoclimate in secondary precious-metal enrichment related to steam-heated acid-sulfate alteration: Econ. Geol. (in press).

Ferguson, H.G., 1928, The Gilbert district, Nevada, in Contributions to Economic Geology (eds. G.F. Loughlin and G.R. Mansfield): U.S. Geological Survey Bulletin 795, p. $125-145$.

Field, C.W., 1966, Isotopic methods for discriminating between sulfates of hypogene and supergene origin: Econ. Geol., v. 61, p. 1428-1435.

Hamlin, S.N., and Alpers, C.N., 1996, Hydrology and geochemistry of acid mine drainage in ground water in the vicinity of Penn Mine and Camanche Reservoir, Calaveras County, California: Second -year summary, 1992-93: U.S. Geological Survey Water-Resources Investigations Report 96-4257, 44 p.

Hendricks, S.B., 1937, The crystal structure of alunite and the jarosites: Am. Mineral., v. 22, p. 773-785.

John, D.A., Thomason, R.G., and McKee, E.H., 1989, Geology and K-Ar geochronlogy of the Paradise Peak mine and the relationship of pre-Basin and Range extension to early Miocene precious-metal mineralization in west-central Nevada: Econ. Geol., v. 84, p. 631-649.

John, D.A., Nash, J.T., Clark, C.W., and Wulftange, W.H., 1991, Geology, hydrothermal alteration, and mineralization at the Paradise Peak gold-silver-mercury deposit, Nye County, Nevada, in Proceedings of the Great Basin Symposium, Geology Society of Nevada, p. 1020-1050.

Kato, T. and Miura, Y., 1977, The crystal structures of jarosite and svanbergite: Mineral. Journal (Japan), v. 8, p. 419-430.

Kubisz, J., 1962, Jarositization of rocks in the upper Silesian coal basin: Bulletin de L'Academie Polonaise Des Sciences, Ser. de Sci. Geol. et Geogr., v. X, no. 1 p. 110.

Mahin, R.A., 1990, The mineralogy and geochemistry of the Apex germanium - gallium mine southwestern Utah: unpub. M.Sc. thesis, Univ. of Utah, 83 p.

Macumber, 1992, Hydrological processes in the Tyrrell Basin, southeastern Australia: Chemical Geology, v. 96, p. 1-18.

Michel, F.A., and Van Everdingen, R.O., 1987, Formation of a jarosite deposit on Cretaceous shales in the Fort Norman area, Northwest Territories: Can. Mineral., v. 25, 221-226.

Nash, J.T., Sims, D.F., and Budge, S., 1985, Geochemical signatures of ores and altered rocks in the Gilbert district, Esmeralda County, Nevada: U.S. Geological Survey Open-File Report 85-259, 17 p.

Nordstrom, D.K., 1982, Aqueous pyrite oxidation and the consequent formation of secondary iron minerals, in Acid Sulfate Weathering (eds. J.A. Kittrick, D.S. Fanning, and L.R. Hossner): Soil Science Society of America Special Publication 10, pp. 27-55.

Petersen, E.U., and Mahin, R.A., 1988, Characteristics and timing of rare metal (Ga, Ge) hydrothermal systems: Apex mine, Tutsagubet district, SW Utah: Geol. Soc. Am. Abstracts with Programs, v. 20, no. 7, p. A142.

Rye, R.O., 1993, The evolution of magmatic fluids in the epithermal environment: The stable isotope perspective: Econ. Geol., v. 88, p. 733-753.

Rye, R.O., and Stoffregen, R.E., 1995, Jarosite-water oxygen and hydrogen isotope fractionations: Preliminary experimental data: Econ. Geol., v. 90, p. 2336-2342.

Rye, R.O., Bethke, P.M., and Wasserman, M.D., 1992, The stable isotope geochemistry of acid sulfate alteration: Econ. Geol., v. 87, 225-262.

Rye, R.O., Bethke, P.M., Lanphere, M.A., and Steven, T.A., 1993, Age and stable isotope systematics of supergene alunite and jarosite from the Creede mining district, Colorado: implications for supergene processes and Neogene geomorphic evolution and climate of the southern Rocky Mountains (abs.): Geological Society of America 
Abstracts with Programs: v., 25, no. p. A274.

Rytuba, J.J., and Heropoulous, C., 1992, Mercury- an important by product in epithermal gold systems: U.S. Geological Survey Bulletin 1877, p. D1-D8.

Sillitoe, R.H., and Lorson, R.C., 1994, Epithermal gold-silver-mercury deposits at Paradise Peak, Nevada: Ore controls, porphyry gold association, detachment faulting and supergene oxidation: Econ. Geol., v. 89, p. 1228-1248.

Steven, T.A., Cunningham, C.G., Naeser, C.W., and Mehnert, H.H., 1979, Revised stratigraphy and radiometric ages of volcanic rocks and minerals deposits in the Marysvale area, west-central Utah: U.S. Geol. Survey Bull. 1469, 40 p.

Stoffregen, R.E., 1993, Stability relations of jarosite and natrojarosite at 100-250 C: Geochimica et Cosmochimica Acta, v. 57, p. 2417-2429.

Stoffregen, R.E., Rye, R.O., and Wasserman, M.D., 1994, Experimental studies of alunite: $\mathrm{I} .{ }^{18} \mathrm{O}-16 \mathrm{O}$ and $\mathrm{D}-\mathrm{H}$ fractionation factors between alunite and water at 250 450 C: Geochimica et Cosmochimica Acta, v. 58, p. 903-916.

Thomason, R.E., 1987, Geology of the Paradise Peak gold/silver deposit, Nye County, Nevada: Bulk mineable Precious Metal Deposits of the Western United States Symposium, Geological Society of Nevada, Guidebook for fieldtrips, p. 250-253.

Vasconcelos, P.M., Brimhall, G. H., Becker, T.A. and Renne, P.R., $1994,{ }^{40} \mathrm{Ar} /{ }^{39} \mathrm{Ar}$ analysis of supergene jarosite and alunite: Implications to the paleoweathering history of the western USA and West Africa: Geochimica et Cosmochimica Acta, v. 58, p. 401-420.

Wasserman, M.D., Rye, R.O., Bethke, P.M., and Arribas, A., 1992, Methods for separation and total stable isotope analysis of alunite: USGS Open-File Report 92-9, 20 p.

Westgate, L.G., and Knopf, A., 1932, Geology and ore deposits of the Pioche district, Nevada: U.S. Geol. Survey Prof. Paper 171.

Zimbelman, D.R., 1996, Hydrothermal alteration and its influence on volcanic hazardsMount Rainier, Washington, a case history: unpub. Ph.D. thesis, University of Colorado, $384 \mathrm{p}$. 


\section{ISOTOPIC AND CRYSTAL CHEMISTRY OF JAROSITE}

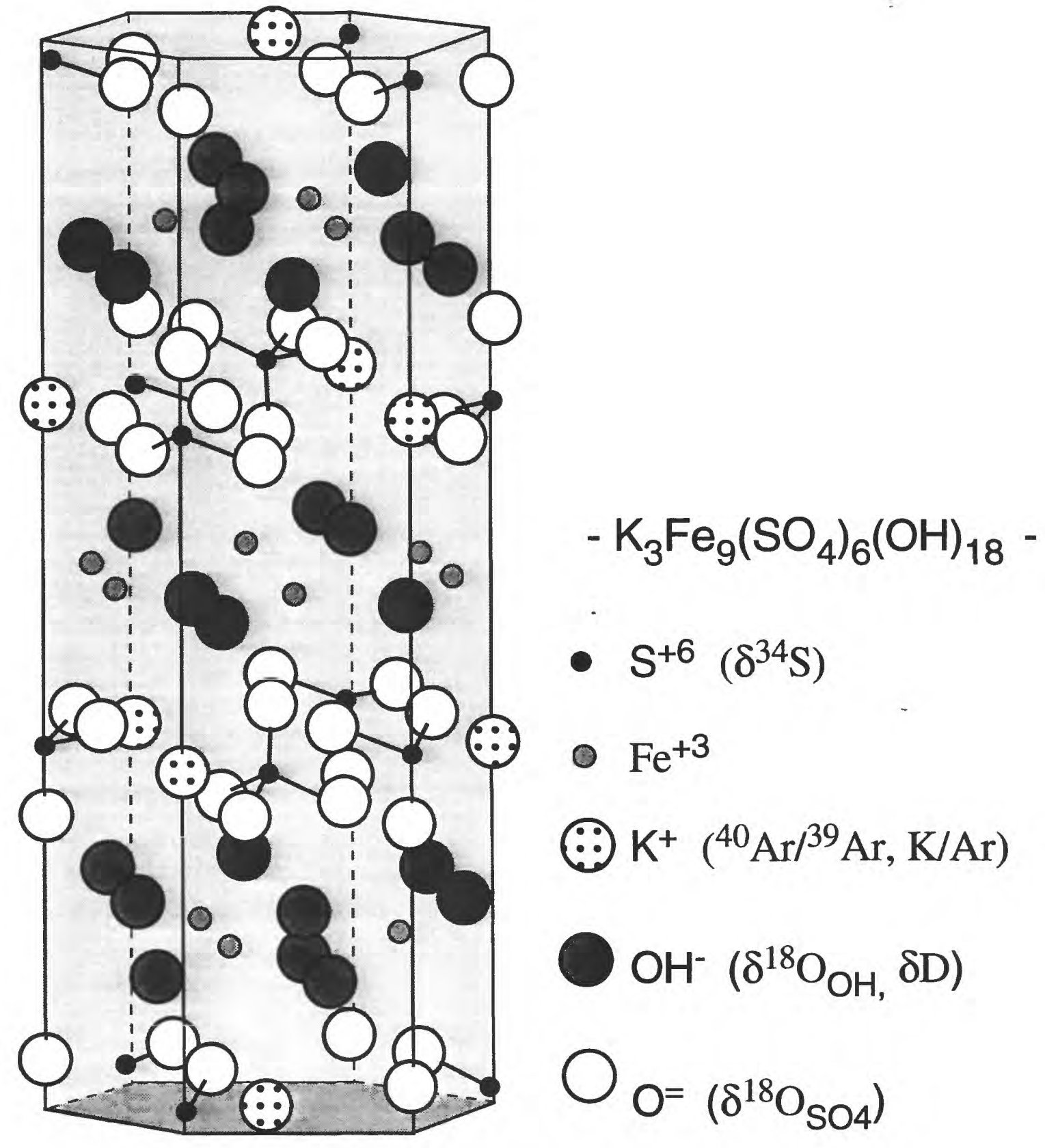

(modified from Brophy et al., 1962 for alunite ) 


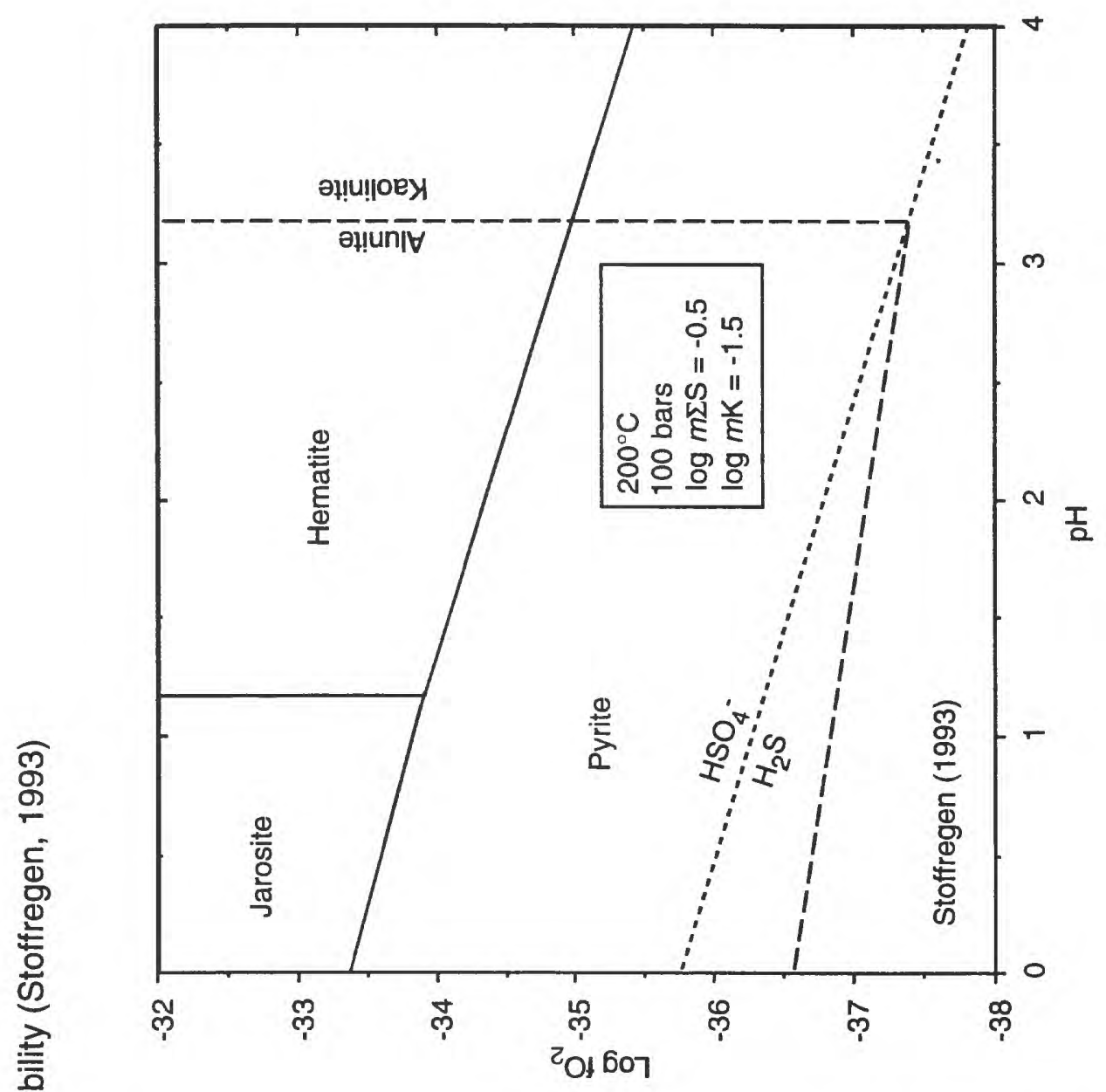

ֻับ

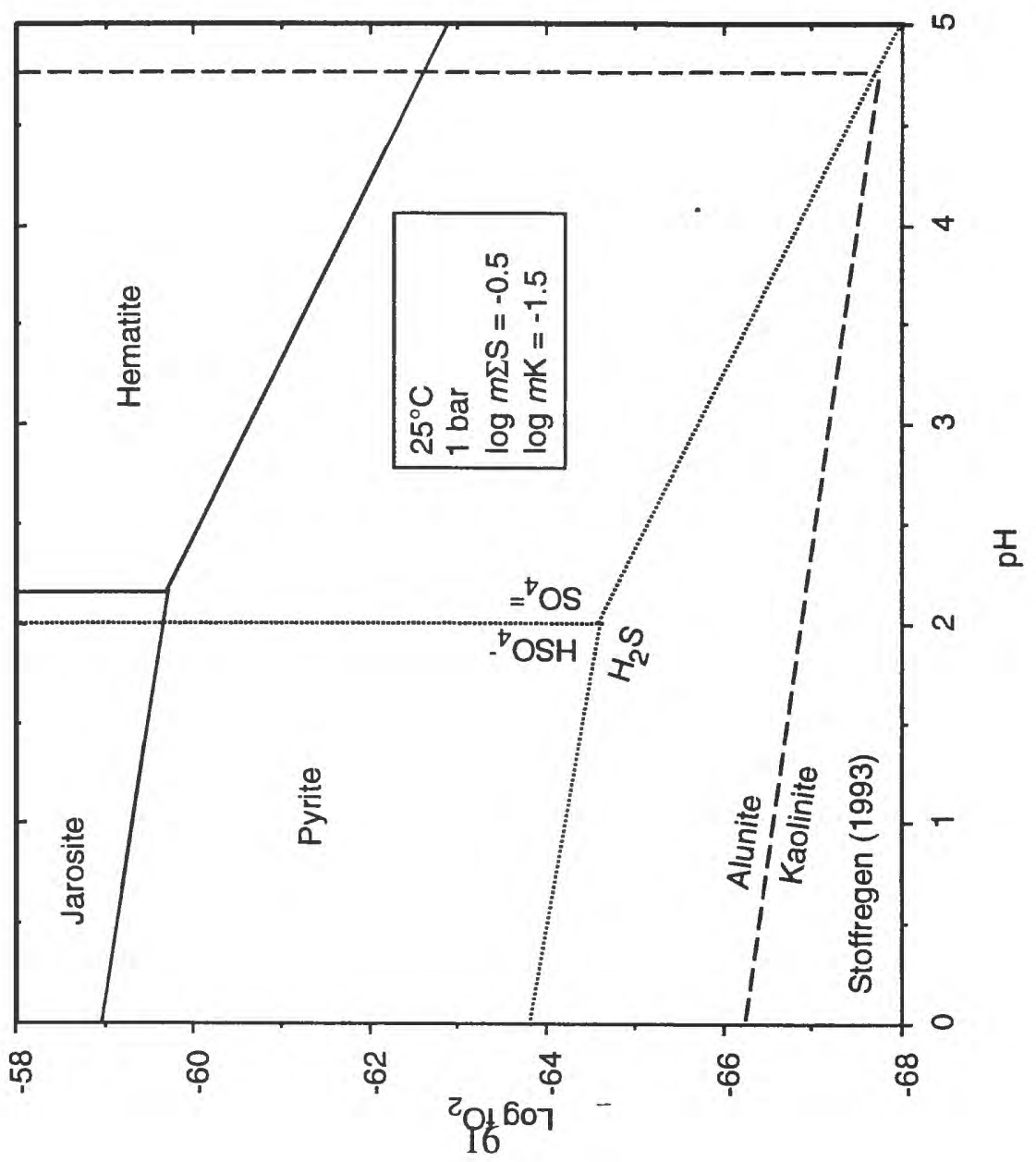




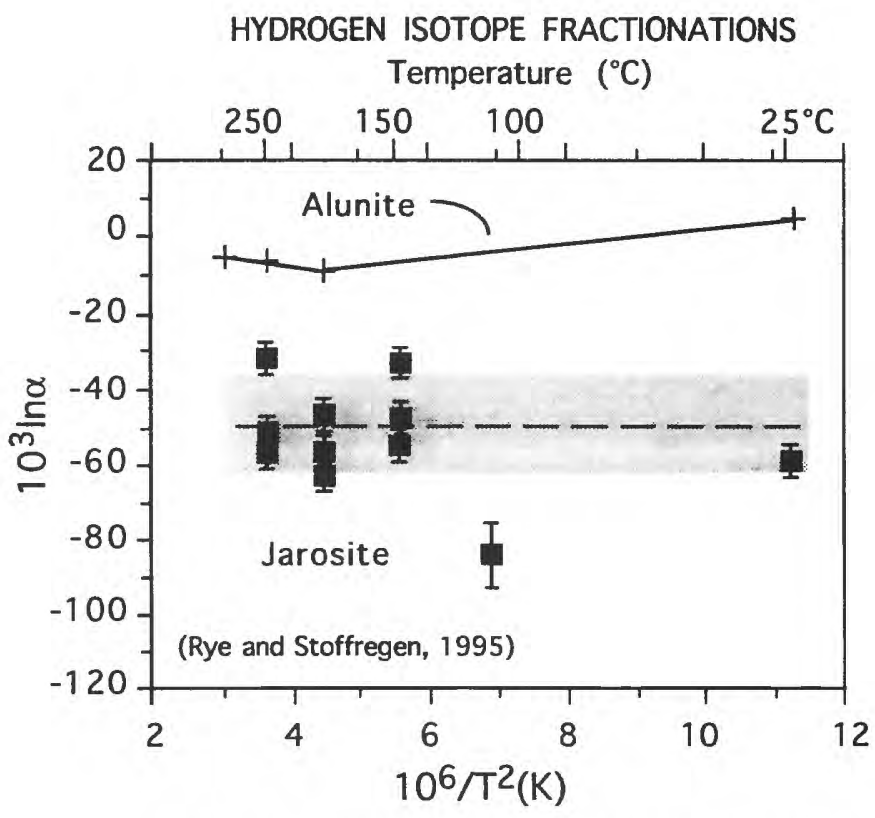

SULFATE OXYGEN ISOTOPE FRACTIONATIONS

Temperature $\left({ }^{\circ} \mathrm{C}\right)$

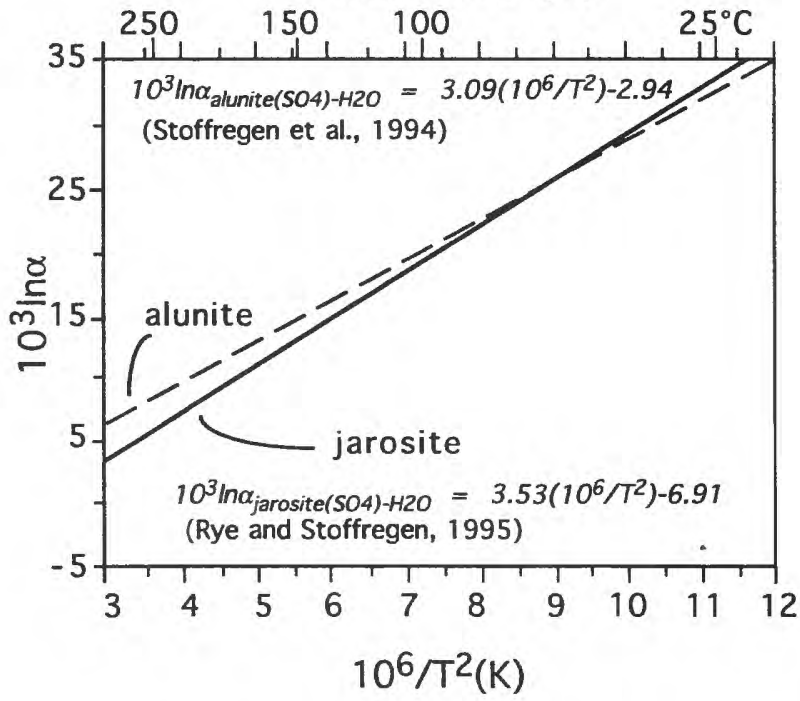

HYDROXYL OXYGEN ISOTOPE FRACTIONATIONS

Temperature $\left({ }^{\circ} \mathrm{C}\right)$

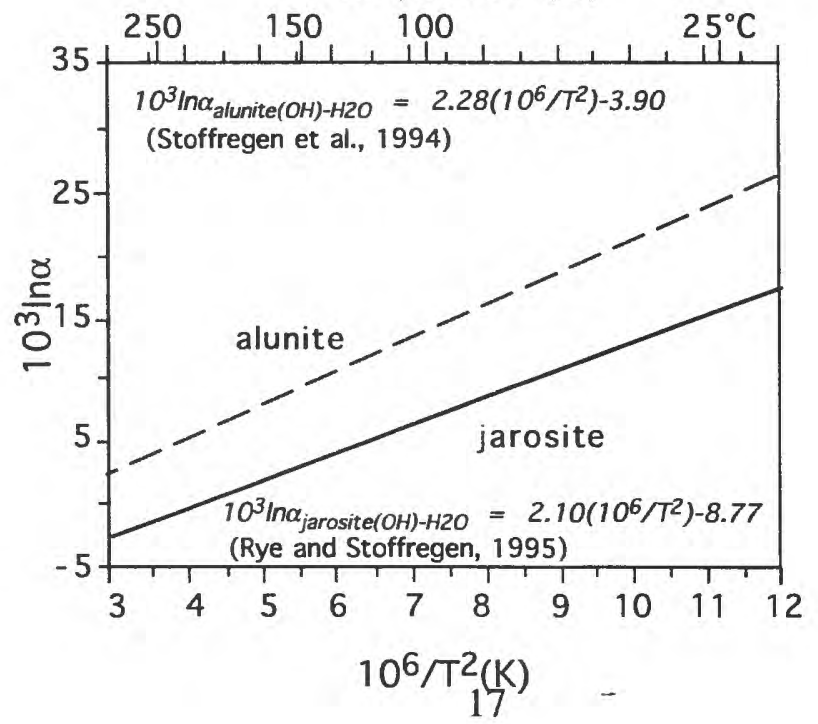

Figure 3 


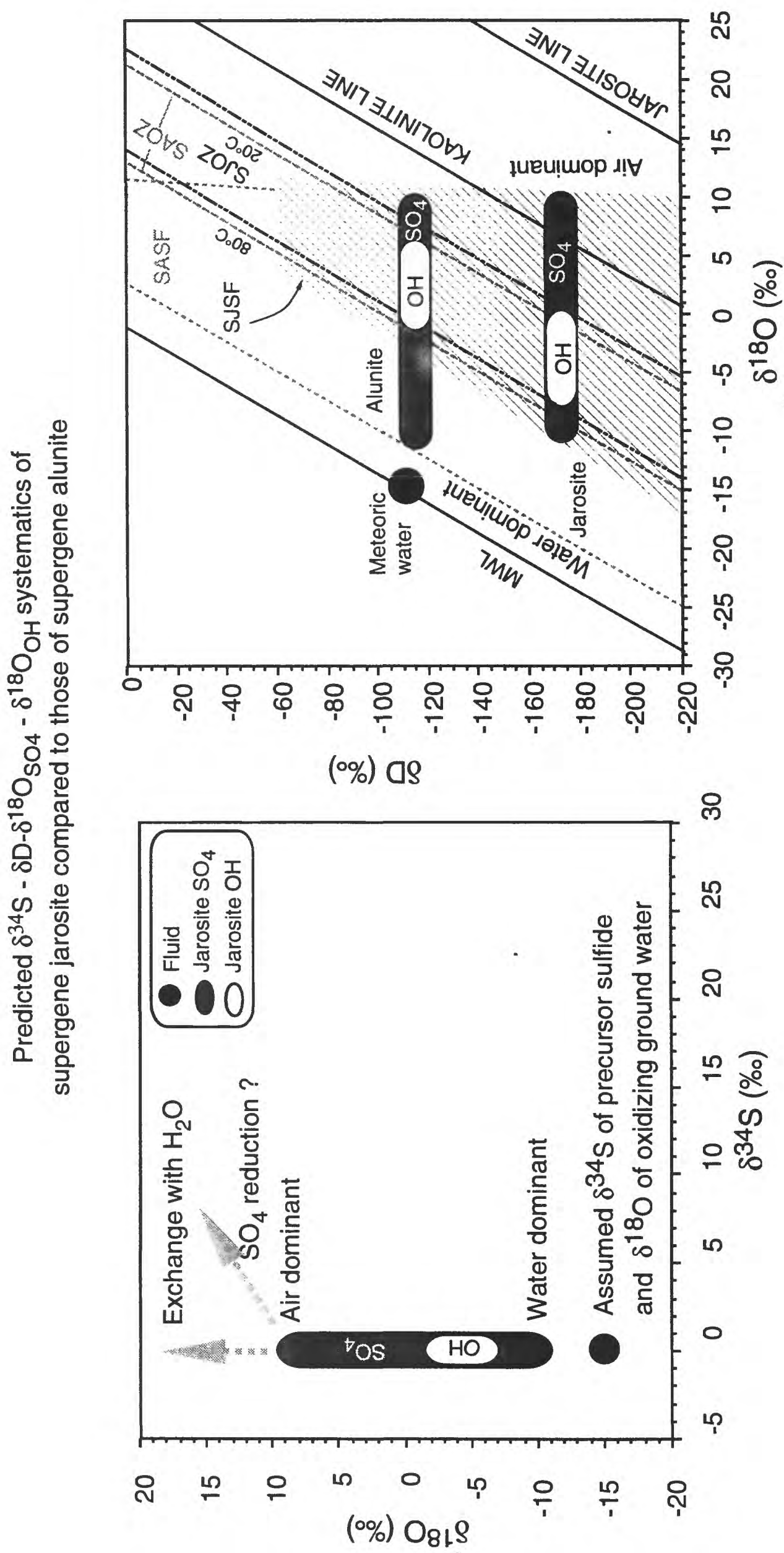




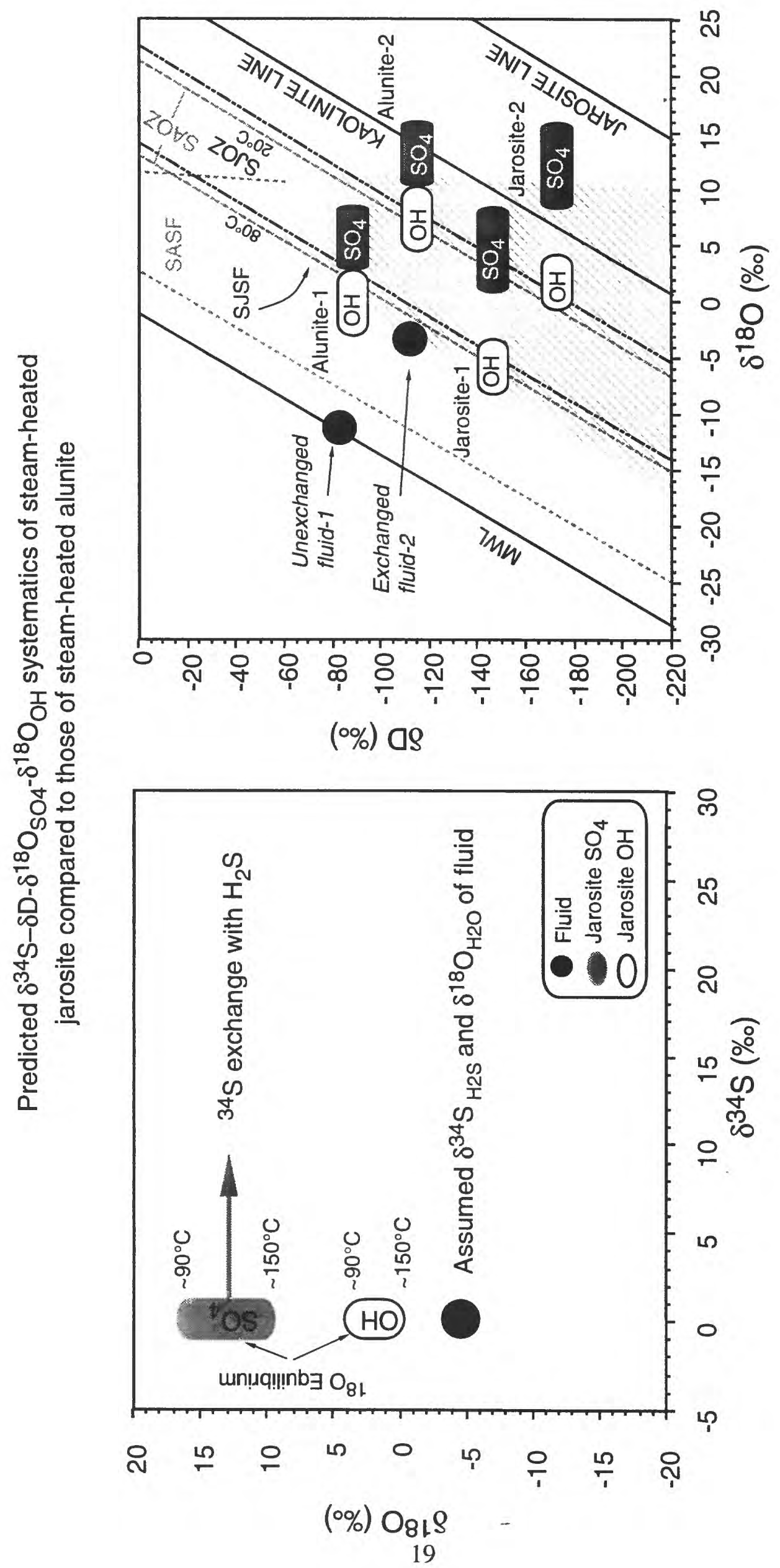




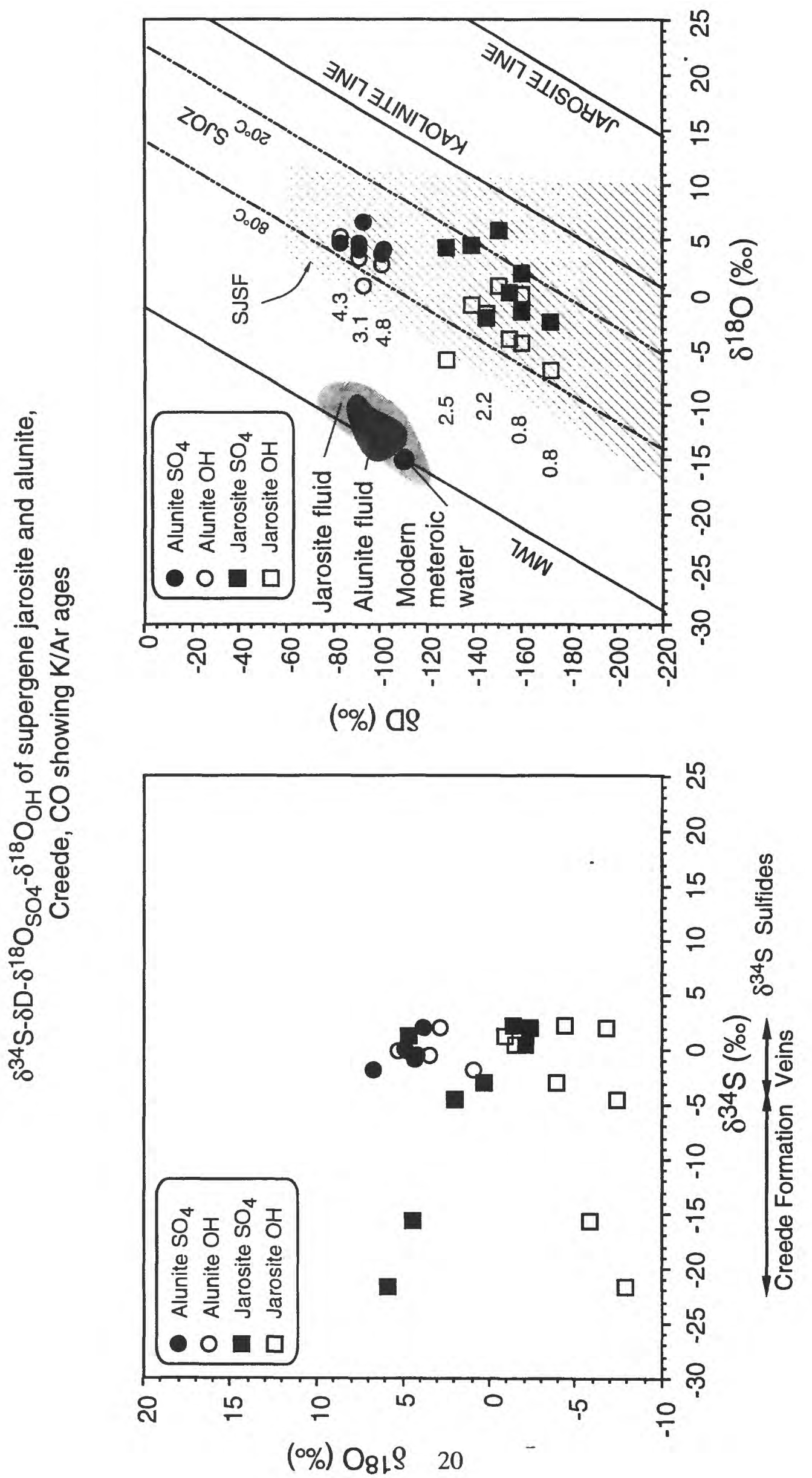




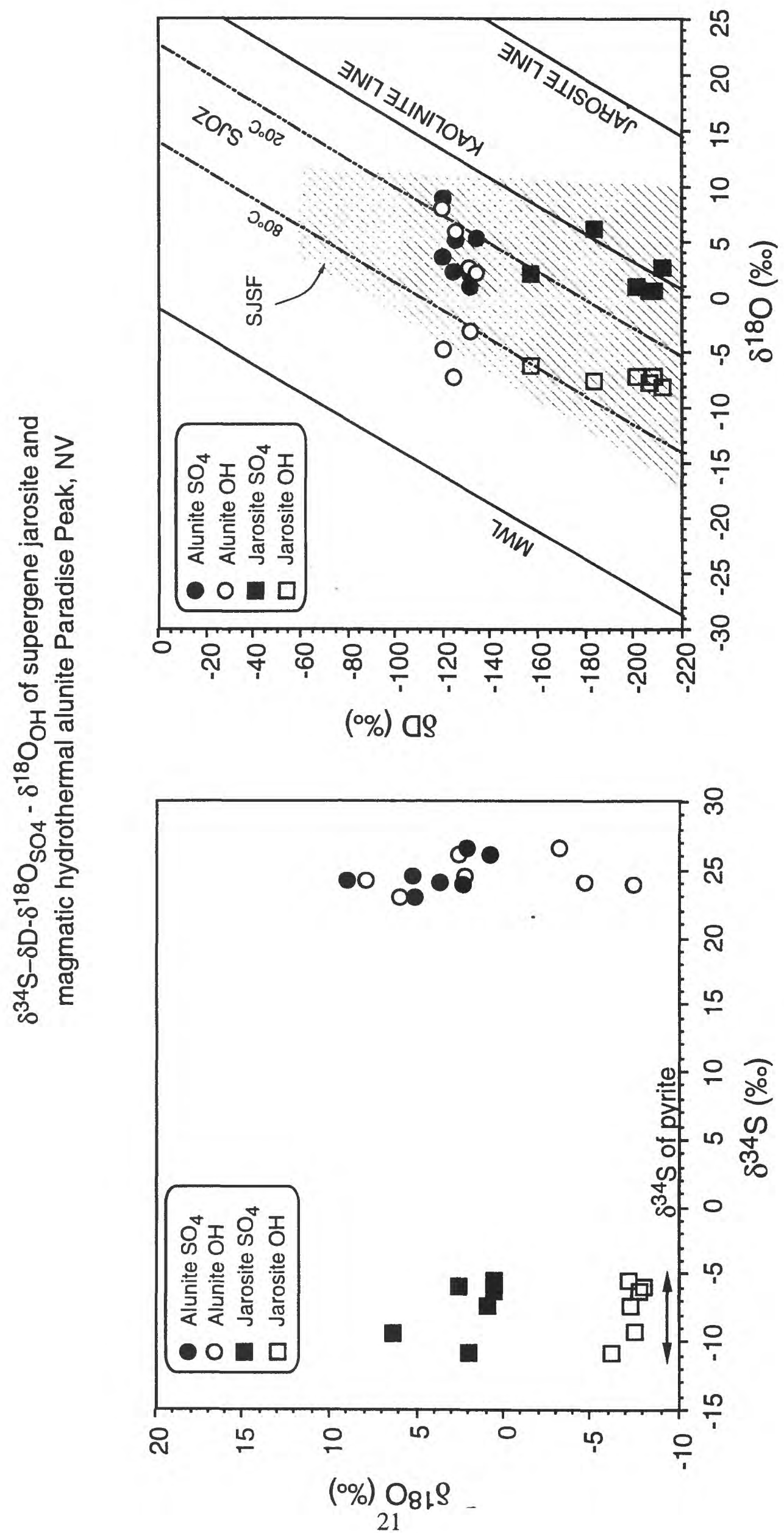




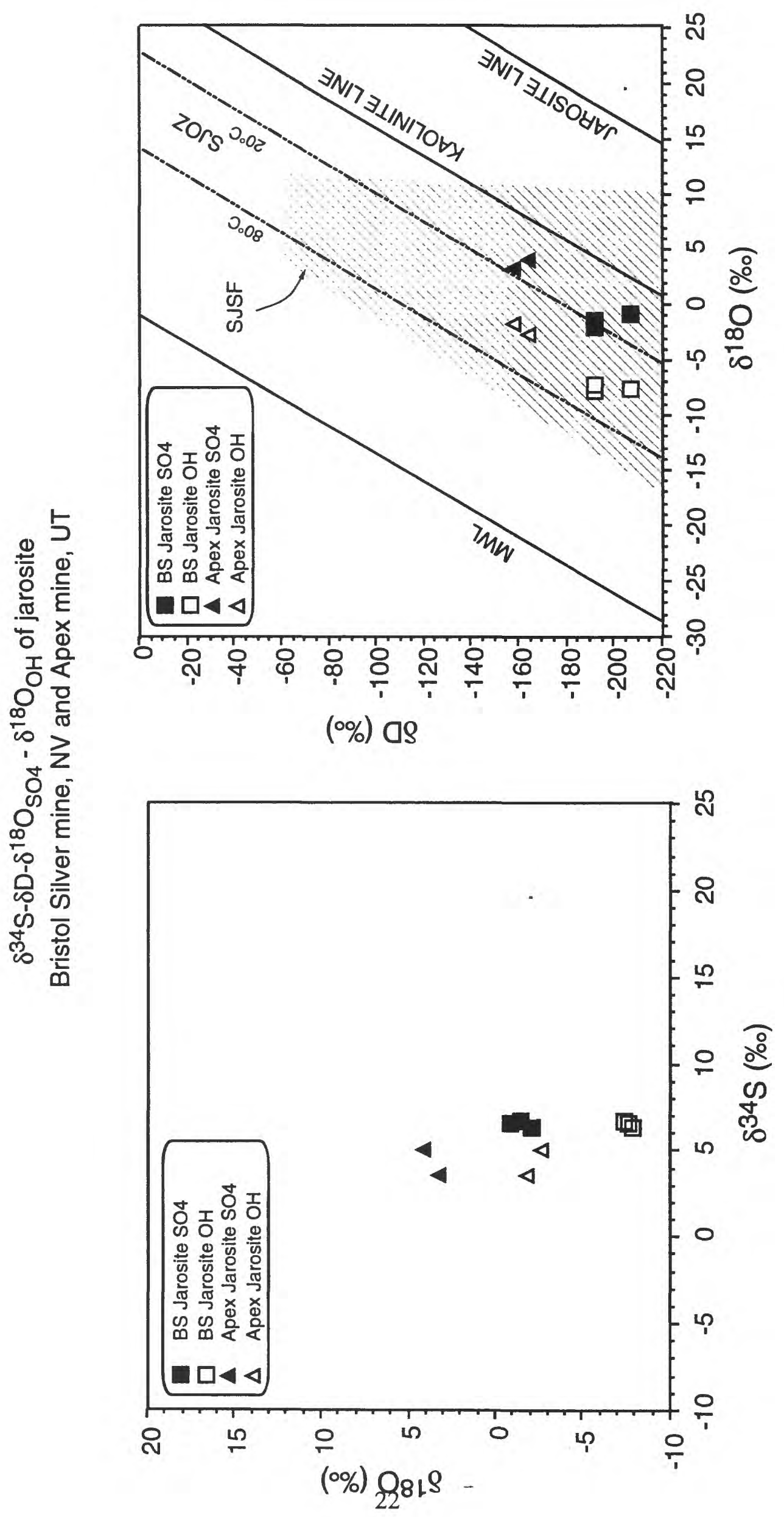

音 

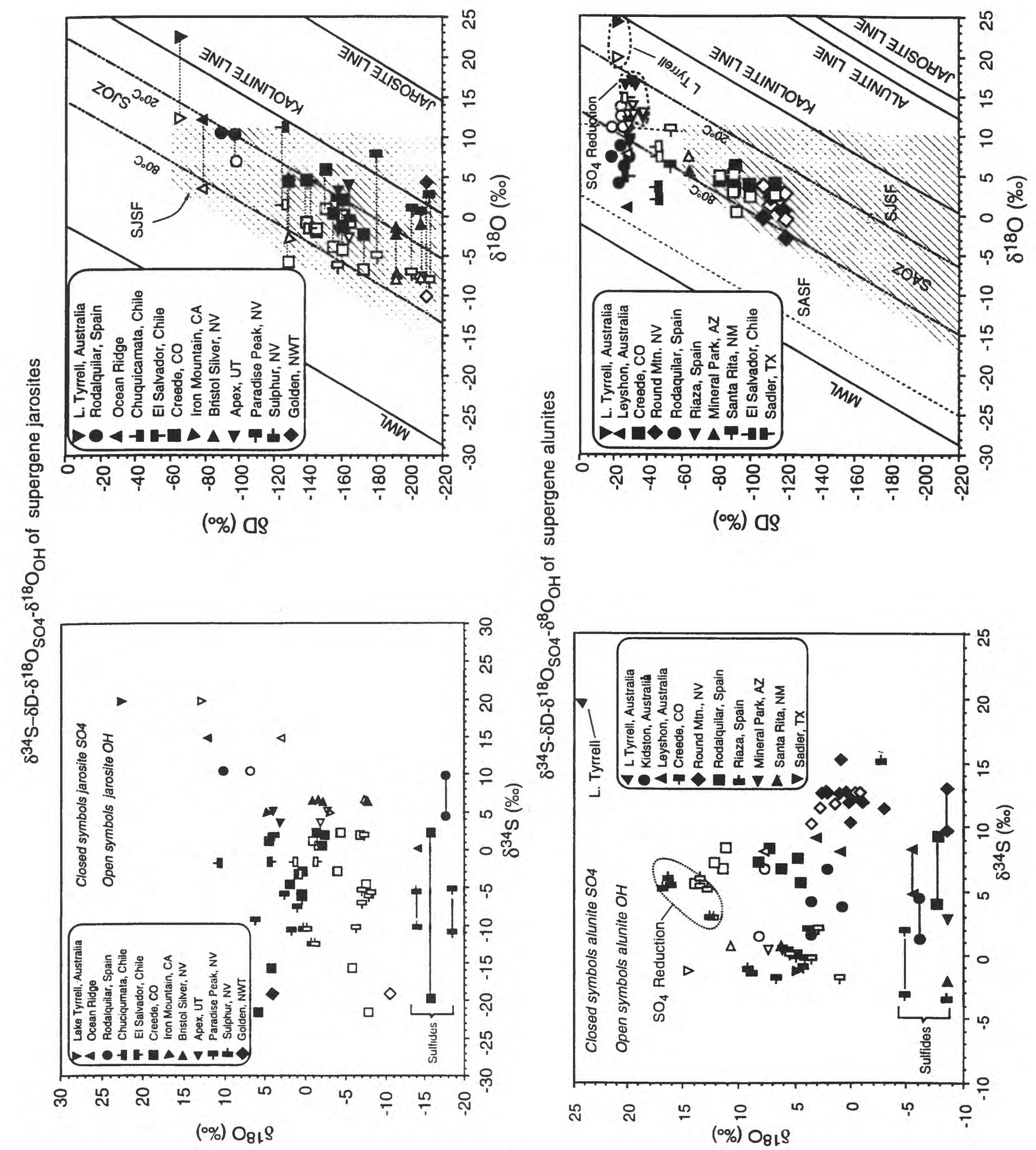


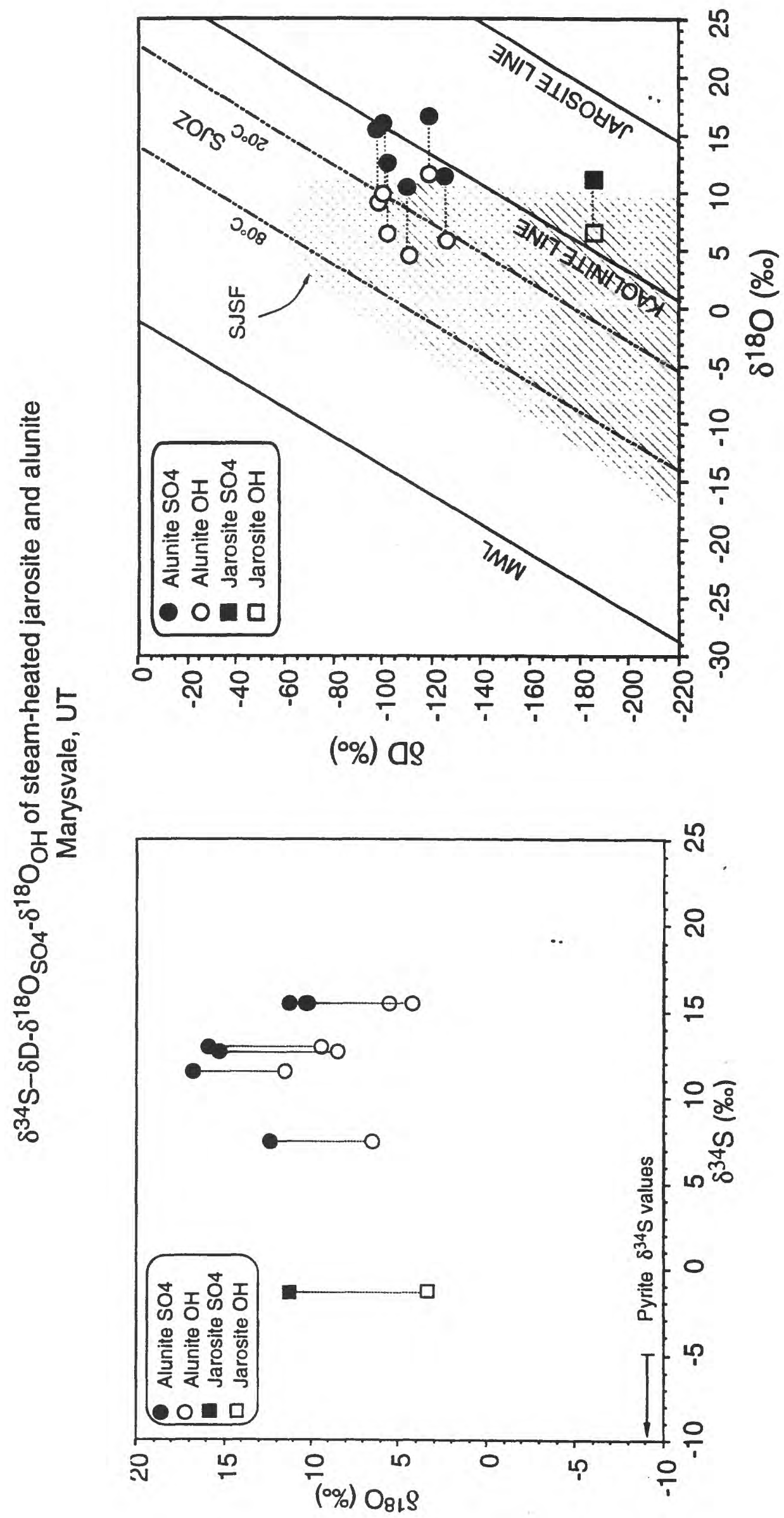

$\frac{0}{\frac{1}{3}}$ 


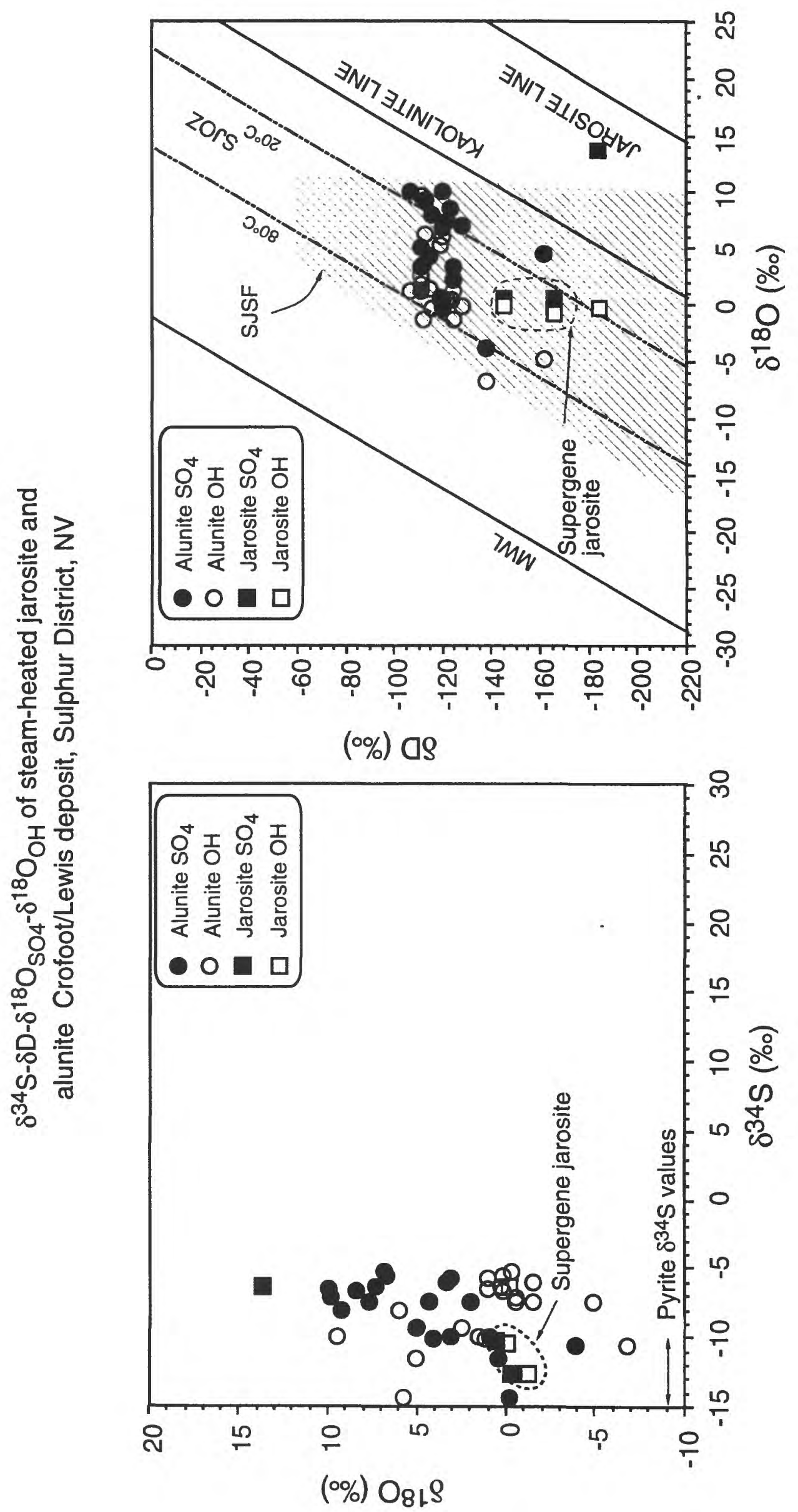




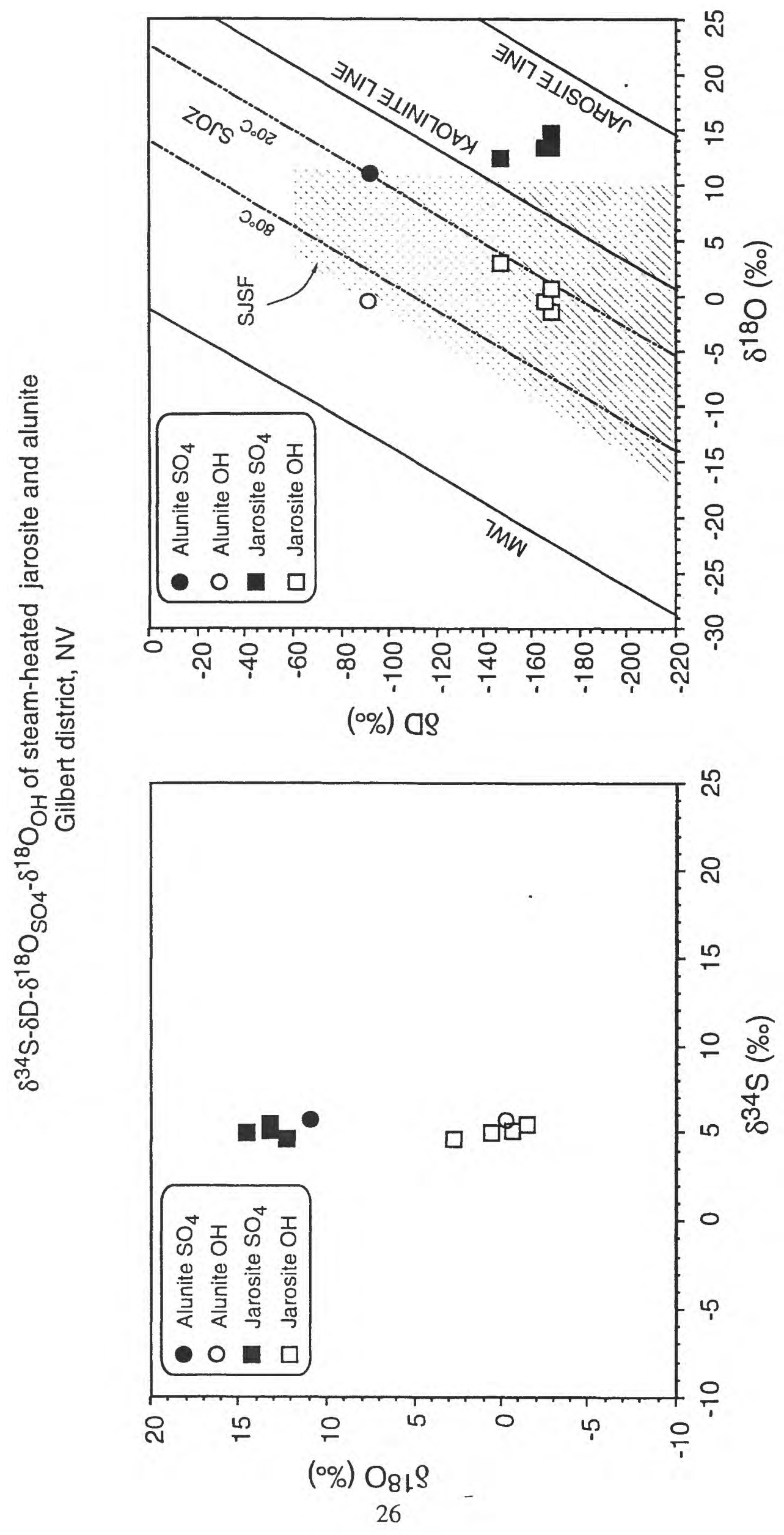

㠃 


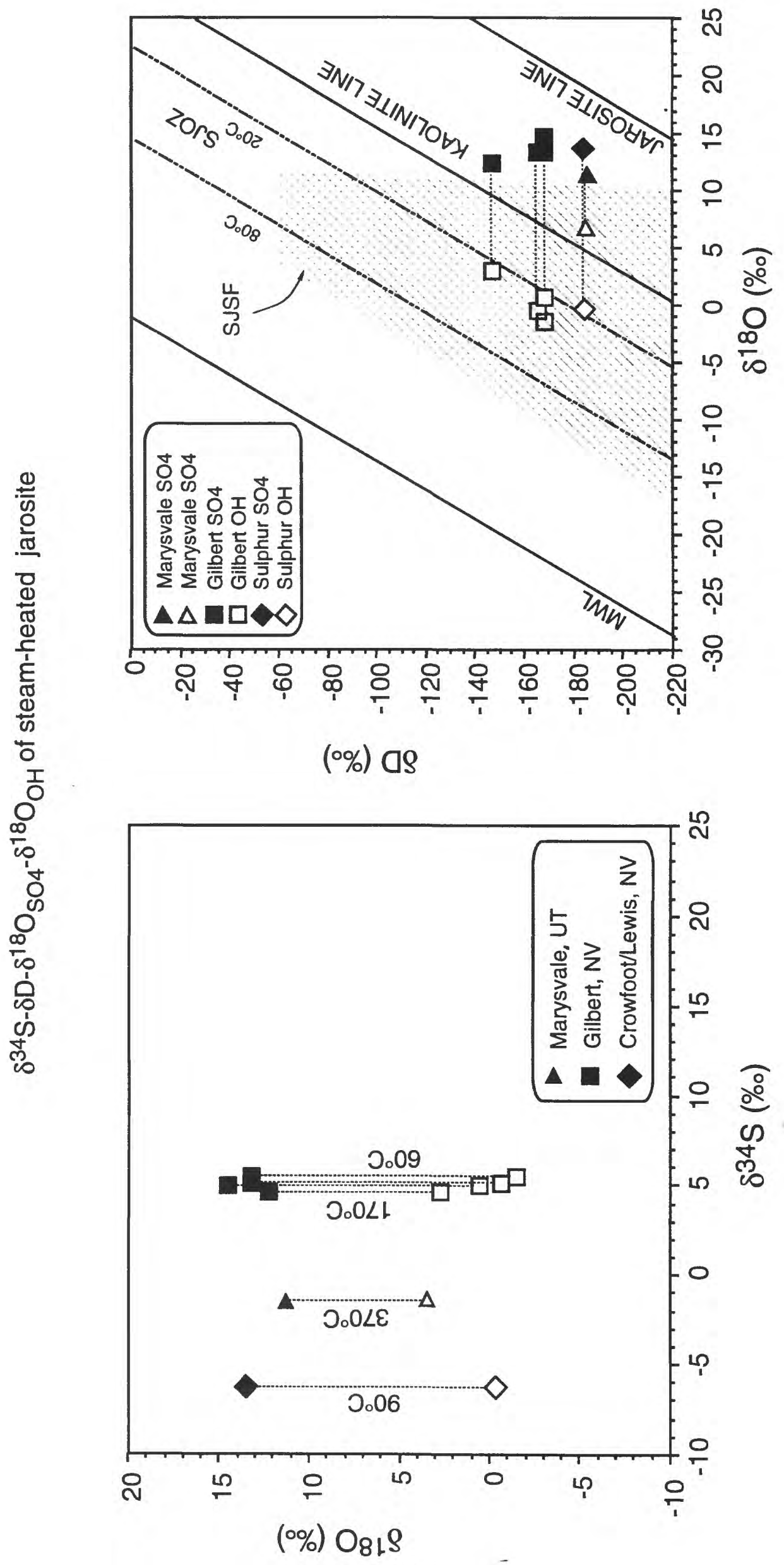




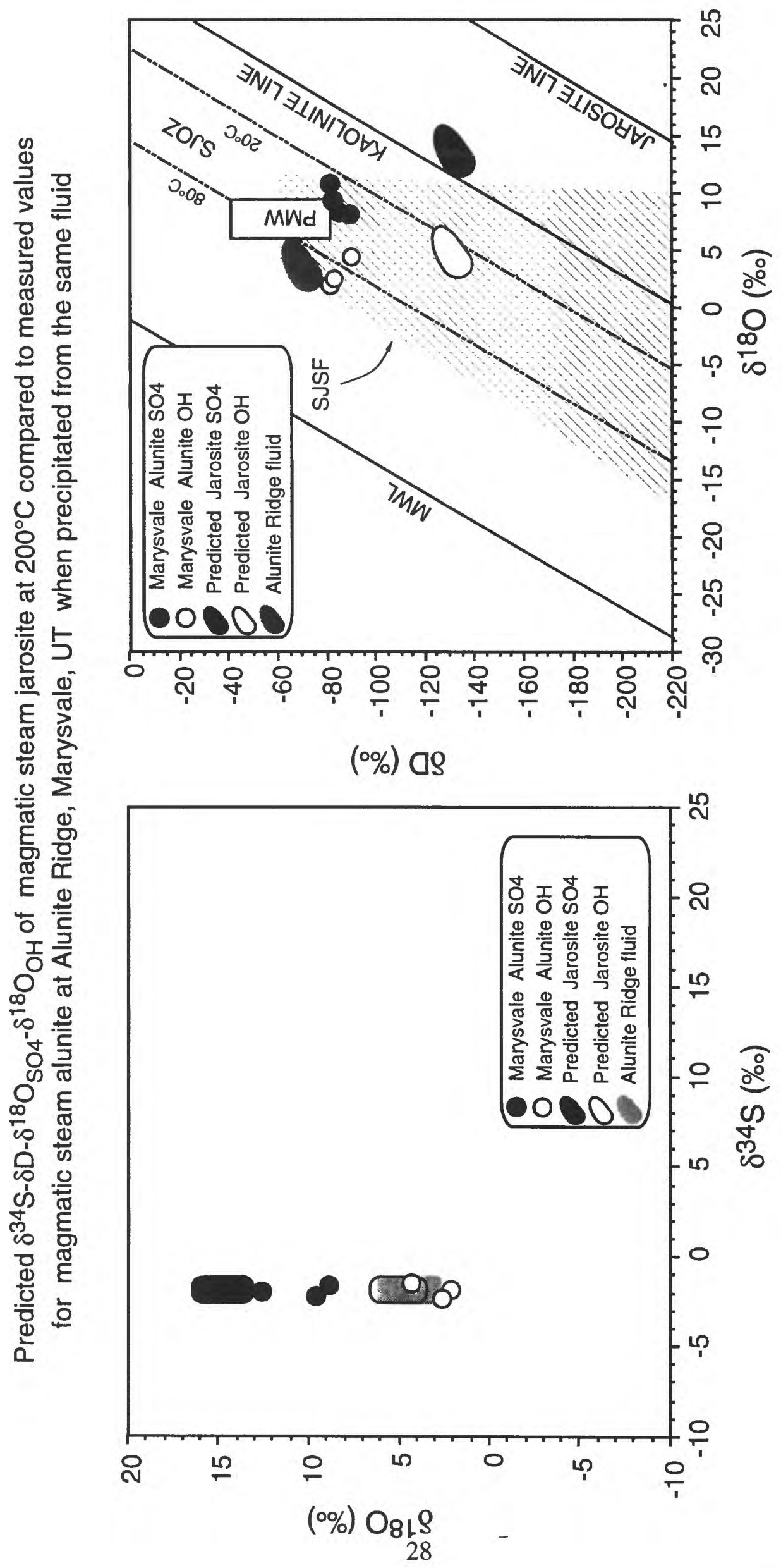

$\frac{\square}{0}$ 